Original Research Paper

\title{
A Comparative Analysis on the Physiological Effects of the Physical and Chemical Properties of the Trihalomethanes on Nutrient Levels, Oxidative Stress and Sterol Compositions of Leaf Oils in Solanum Lycopersicum Cultivars
}

\author{
${ }^{1}$ Babatunde C. Akande, ${ }^{1}$ Olalekan S. Fatoki, ${ }^{1}$ James P. Odendaal, \\ ${ }^{2}$ Jeanine L. Marnewick, ${ }^{3}$ Patrick Ndakidemi and ${ }^{4}$ Olatunde S. Olatunji \\ ${ }^{I}$ Faculty of Applied Science, Cape Peninsula University of Technology, \\ Cape Town Campus, Keizersgracht, P.O. Box652, Cape Town 8000, South Africa \\ ${ }^{2}$ Oxidative Stress Research Centre, Faculty of Health and Wellness Sciences, \\ An Institute of Biomedical and Microbial Biotechnology, Cape Peninsula University of Technology, \\ Bellville Campus, P.O. Box 1906, Bellville 7535, South Africa \\ ${ }^{3}$ School of Life Sciences, Nelson Mandela African Institute of Science and Technology, P.O. Box447, Arusha, Tanzania \\ ${ }^{4}$ School of Chemistry and Physics, College of Agriculture, Engineering and Sciences, \\ University of Kwazulu-Natal, Durban 4000, South Africa
}

Article history

Received: 07-11-2017

Revised: 08-03-2018

Accepted: 11-05-2018

Corresponding Author:

Olatunde S Olatunji

School of Chemistry and

Physics, College of Agriculture,

Engineering and Sciences,

University of Kwazulu-Natal,

Durban 4000, South Africa

Tel: +27797380934

Fax: +27214603905

Email: snf_olatunji@ymail.com

\begin{abstract}
Trihalomethane group of disinfection by-products was used to evaluate the magnitude of physiological changes induced on nutrient levels, oxidative stress and phytosterol content in two tomato cultivars. The tomato cultivars were grown as potted plants in a greenhouse and exposed to the varying concentrations of trihalomethanes and organochlorines via irrigation water for a period of 30 days. The concentration levels of nitrogen, potassium and boron in both cultivars significantly $(p<0.05)$ decreased with increasing chlorination. A significant $(\mathrm{p}<0.05)$ increase in total polyphenol content, Ferric Reducing Antioxidant Power (FRAP) and guaiacol peroxidase activity was observed in both cultivars. Increase in chlorination could probably be partly responsible for the induction of a greater antioxidant response, as well as the increased free phytosterol content in the tomatoes leaf oils, while $\beta$-sitosterol content decreased. In general, the magnitude of the effect of the increasing number of chlorine atoms in the trihalomethane structure were greater than the effects of increasing concentration on nutrient levels. Although, trihalomethanes induced significant physiological changes in some of the measured parameters, no plant mortality was recorded even at the highest concentrations.
\end{abstract}

Keywords: Antioxidants, Halogenation, Nutrient Concentration, Oxidative Stress, ROS, Tomato

\section{Introduction}

The advent of industrialisation gave rise to the increased use of chlorinated and brominated refractory organics worldwide. Traces of these halogenated refractory organics have been found in the terrestrial, hydrological and atmospheric environments (Habartová et al., 2013; Li et al., 2015; Montelius et al., 2015). As such, concerns have been raised on the carcinogenic and mutagenic potential of these halogenated refractory organics (Woo et al., 2013; Pi et al., 2016).
The terrestrial environment receives a heavy load of these organohalogens; hence, plant exposure to these compounds was imminent. This generated the interest of the earlier scientific community aiming to understand the mechanisms of plant detoxification of organohalogens. Findings from a number of research studies suggested four possible mechanisms for the removal of organohalogens in plants. These include: the rapid sequestration and partitioning of organohalogens to lipophyllic plant cuticles (Moeckel et al., 2007); phyto-reduction of organohalogens to less halogenated metabolites (Nzengung and Jeffers, 2001); phyto-oxidation of organohalogens to halo-ethanols 
or haloacetic acids (Reichenauer and Germida, 2008) and the assimilation of organohalogens as non-phytotoxic metabolites into plant tissues (Susarla et al., 2002). The role of plant oxygenase and dehalogenase enzymes on the isolation, structure and detoxification mechanisms of organohalogens was also reported (Wolfe and Hoehamer, 2003; Van Aken, 2011; San Miguel et al., 2013).

The initial contact physiological and morphological response mechanisms of plants to chlorinated organics have been reported (Faure et al., 2012; San Miguel et al., 2012; Ahammed et al., 2013; Guittonny-Philippe et al., 2015). Imfeld et al. (2009); Doucette et al. (2013); and Chen et al. (2014), also noted that some plants have the ability to stimulate the removal of chlorinated organic pollutants through plant uptake, phytovolatilization and/or phytodegradation. San Miguel et al. (2012) were the first to associate increasing halogenation with increasing oxidative stress, in their study on the physiological response of Zea Mays to monochloro-, 1,4-dichloro- and 1,2,4-trichlorobenzenes. However, there are several physical and chemical properties of organohalogens that influence their phytotoxic responses in different plant types.

\section{Trihalomethanes and Plant Response}

The trihalomethanes which include Bromodichloromethane $\left(\mathrm{CHBrCl}_{2}\right)$, bromoform $\left(\mathrm{CHBr}_{3}\right)$, chloroform $\left(\mathrm{CHCl}_{3}\right)$ and dibromochloromethane $\left(\mathrm{CHBr}_{2} \mathrm{Cl}\right)$ are the organohalogens classified as persistent bioaccumulative toxins (PBT) (Wong et al., 2012). Despite this, they are widespread and detected in most surface water bodies. An evaluation of the molecular structures of the listed trihalomethanes revealed an increasing order of both bromination $\left(\mathrm{CHCl}_{3}<\mathrm{CHBrCl}_{2}<\mathrm{CHBr}_{2} \mathrm{Cl}<\mathrm{CHBr}_{3}\right)$ and chlorination $\left(\mathrm{CHBr}_{3}<\mathrm{CHBr}_{2} \mathrm{Cl}<\mathrm{CHBrCl}_{2}<\mathrm{CHCl}_{3}\right)$. Therefore, the molecular structure of trihalomethanes allows for the evaluation of the physiological response of plants (such as the tomato cultivars) with respect to the halogen reactivity series.

The non-structural content of plants such as phenolic compounds are known to perform a wide variety of functions which include acting as antioxidants (Ainsworth and Gillespie, 2007). Plants contain a wide range of antioxidant molecules and enzymes which are able to maintain intracellular Reactive Oxygen Species (ROS) levels. When exposed to chemical stressors, they undergo oxidative stress which results from the imbalance between the production of ROS and their removal by antioxidants (Phung and Jung, 2015; Talbi et al., 2015). Most antioxidant defences which are stimulated by abiotic factors such as light stress and drought in plants, are also stimulated by organic pollutants (Wang et al., 2008; Yang et al., 2008; Faure et al., 2012). They may as well exhibit nonenzymatic antioxidant responses which are measured using indices such as total Phenolic Content (TPC), Ferric Reducing Antioxidant Power (FRAP) and the
Oxygen Radical Absorbance Capacity (ORAC). The FRAP assay can measure the antioxidant reducing potential of most biological fluids (Benzie and Strain, 1996), while ORAC assay measures the inhibition of free radical damages to a fluorescent probe by antioxidants. The delay in the degradation of the fluorescent probe may be suggestive of the ability of the pre-existing antioxidants to scavenge the free radicals (Prior et al., 2003).

Lipid oxidation for instance, is particularly dangerous because it propagates the production of free radicals through so-called 'chain reactions. Severe lipid peroxidation leads to the breakdown of membrane function, followed by the disintegration of organelles, oxidation and dysfunction of proteins, DNA and RNA (Gutteridge and Halliwell, 2000; Farmer and Mueller, 2013). The end products of lipid peroxidation may include aldehydic secondary products (malondialdehyde, 4-hydroxy-2-nonenal, 4-hydroxy-2-hexenal and acrolein), which are markers of oxidative stress (Lykkesfeldt, 2007; Farmer and Mueller, 2013). They are easy to measure by using the thiobarbituric acid assay (TBARS) for malondialdehyde (Hodges et al., 1999). Common free phytosterols found in plant oils are stigmasterol, $\beta$ sitosterols and campesterol. Sterols have been known to exhibit antioxidant properties attributed to their ability to form allylic free radicals that isomerizes to other stable free radicals (Ramadan and Moersel, 2006).

Typical enzymatic responses for the scavenging of ROS in plants include the measurement of the activity of antioxidant enzymes such as Ascorbate Peroxidase (APX), Guaiacol Peroxidase (GPX) and Superoxide Dismutase (SOD) (Jebara et al., 2005). Superoxide Dismutase (SOD; EC 1.15.1.1) is an enzyme that catalyses the dismutation of the toxic superoxide $\left(\mathrm{O}_{2}^{-}\right)$ radicals into molecular Oxygen $\left(\mathrm{O}_{2}\right)$ and hydrogen peroxide $\left(\mathrm{H}_{2} \mathrm{O}_{2}\right)$ (Barondeau et al., 2004). Ascorbate peroxidase (APX; EC 1.11.1.11) is the enzyme that detoxifies peroxide $\left(\mathrm{H}_{2} \mathrm{O}_{2}\right)$ using ascorbate as a substrate, to transfer electrons to peroxide, producing dehydroascorbate and water as products (Pang and Wang, 2010). Guaiacol peroxidase (GPX; EC 1.11.1.7) is an enzyme in the peroxidase group that detoxifies peroxide $\left(\mathrm{H}_{2} \mathrm{O}_{2}\right)$ using guaiacol (2-methoxyphenol) as its reducing substrate (Mika and Lüthje, 2003).

In this study, the effects of the increasing halogenation of trihalomethanes on the phytosterol content of leaf oils was investigated. The tomato cultivars popularly known as "moneymaker" and "star" were selected based on their popularity, high yields and stability in the Southern climate regions. More also, tomato plants was recently reported to demonstrate capacity for the uptake of organochlorine compounds (Zhang et al., 2015). The non-enzymatic and enzymatic responses to oxidative stress with the peroxidation of lipids membrane, induced by increasing concentration and halogenation of trihalomethanes in the tomato cultivars were evaluated. The physiological changes in the 
tomato cultivars in response to increasing halogenation (a key chemical property) and concentration of trihalomethanes (a key physical property), may be evaluated in terms of the magnitude of the differences in the levels of selected key macro and micro nutrients, different levels in oxidative stress and sterol content in leaf oils. In addition, the effects of increasing halogenation on sterol compositions in plant leaf oils was also investigated in tomato plants.

\section{Materials and Methods}

\section{Chemicals}

The chemicals used in this study include bromodichloromethane $\left(\mathrm{CHBrCl}_{2}\right)$, bromoform $\left(\mathrm{CHBr}_{3}\right)$, chloroform $\left(\mathrm{CHCl}_{3}\right)$ and dibromochloromethane $\left(\mathrm{CHBr}_{2} \mathrm{Cl}\right)$ which were purchased at Sigma-Aldrich (South Africa) as pure standards (99\% of purity). They were all provided directly solubilized in methanol.

\section{Plant Materials, Exposure Time and Treatments}

The $2 \times 4 \times 5$ factorial experiments were laid out in a completely randomized block design with four replications. The experiment commenced with the design of a 160 pot irrigation system fitted with timers and connected to 20 separate $68 \mathrm{~L}$ rough tote plastic reservoirs. Twenty $6 \mathrm{~m}$ long square plastic gutters containing 8 pots each were arranged on an elevated table in the greenhouse. The $12.5 \mathrm{~cm}$ plastic square pots were filled with Starke-Ayres organic potting soils with a Nitrogen, Phosphorus and Potassium (NPK) ratio of 3:1:5. Each pot was connected to $4 \mathrm{~L}$ per hour button dripper extended from $20 \mathrm{~mm}$ Low-Density Polyethylene (LDPE) irrigation pipe. Each $68 \mathrm{~L}$ plastic reservoir was fitted with 1,400 liters per hour submersible pump. Holes with diameters of $21 \mathrm{~mm}$ were made on each lid allowing the LDPE pipes connected to the submersible pumps to pass through. The reservoir lids remained closed to prevent loss of trihalomethanes to evaporation due to its classification as a semi-volatile compound. The irrigation timers were set to water the plants twice a day from $8.00 \mathrm{am}-8.30 \mathrm{am}$ and $8.00 \mathrm{pm}-8.30 \mathrm{pm}$ approximately giving each pot $4 \mathrm{~L}$ of water per day.

To eliminate nutrient stress, de-ionized water pretreated with granular activated carbon removing other potential organic water pollutants was mixed with StarkeAyres nutrified K2025 water-soluble fertilizer in the reservoirs for the entire duration of the experiment. Seeds of the $S$. lycopersicum cultivars tomato Money Maker (TMM) and the tomato Star (TS) were purchased from the StarkeAyres Garden Centre and soaked in nanopure water for one hour to remove all preservatives. The first four pots in each plastic gutter contained seeds of the variety TMM and the last four pots contained seeds of the variety TS. All seeds emerged within 7 days after planting and the weaker seedling was uprooted leaving one seedling per pot 14 days after planting. The treatments began 16 days after emergence when all plants were within the range of 30-35 $\mathrm{cm}$ in height. The 160 pot plants were divided into four groups each containing 40 pot plants. The $1^{\text {st }}$ group was exposed to varying Concentrations of Bromodichloromethane $\left(\mathrm{CHBrCl}_{2}\right)$, the $2^{\text {nd }}$ group to bromoform $\left(\mathrm{CHBr}_{3}\right)$, the $3^{\text {rd }}$ group to Chloroform $\left(\mathrm{CHCl}_{3}\right)$ and the last group to dibromochloromethane $\left(\mathrm{CHBr}_{2} \mathrm{Cl}\right)$. In each group, plants in the first gutter continued to receive deionized water and the nutrient solution only (control). Plants in gutters 2-5 were treated differentially by varying the concentration of trihalomethanes in their reservoirs. Plants in gutters 2-5 were exposed to concentrations of $2.5 \mathrm{mg} . \mathrm{L}^{-1}$, $5.0 \mathrm{mg} . \mathrm{L}^{-1}, 7.5 \mathrm{mg} . \mathrm{L}^{-1}$ and $10 \mathrm{mg} . \mathrm{L}^{-1}$ of the designated trihalomethane diluted with de-ionized water and nutrient solution. The treatment was terminated after a 30-day exposure of the plants to the trihalomethanes. The leaves of each plant were cut from the stem and immediately dipped in liquid nitrogen and stored in the Nuaire glacier ultra-low minus $86^{\circ} \mathrm{C}$ freezer (Nuaire, Plymouth, USA) for oxidative stress and lipid profile determination. The rest of the plants were washed with de-ionized water to remove all soil particles, put in paper bags and dried at $65^{\circ} \mathrm{C}$ for $72 \mathrm{~h}$. to stop enzymatic activity for nutrient level analysis (Havlin et al., 2012).

\section{Determination of Plant Mineral Nutrient Concentration}

Changes in the primary macronutrients, Nitrogen $(\mathrm{N})$, Phosphorus $(\mathrm{P})$, potassium $(\mathrm{K})$, the three secondary macronutrients, Calcium $(\mathrm{Ca})$, Sulfur $(\mathrm{S})$, magnesium $(\mathrm{Mg})$ and the micronutrients Boron (B), Manganese (Mn), iron $(\mathrm{Fe})$, zinc $(\mathrm{Zn})$, copper $(\mathrm{Cu})$ and sodium $(\mathrm{Na})$ content of plant extracts were investigated. Homogenization of the dried plant material was achieved using the micro plant grinder model FZ102 (Tianjin taisite instruments, Tianjin, China). The homogenized plant powders were weighed and stored in $10 \mathrm{~cm}$ long airtight cylindrical glass vials. The air blower was used to clean the grinder before the next sample was homogenized so as to prevent sample mixing. The samples were sent off to Bemlab analytical laboratory where they were ashed at $480^{\circ} \mathrm{C}$, shaken and digested with a $50: 5032 \% \mathrm{HCL} /$ water solution for extraction through filter paper (Campbell and Plank, 1998). The primary and secondary macronutrients with the micronutrients content of the extract were measured with a Varian ICP-OES optical emission spectrometer (Varian Vista-Pro, Springvale, Australia) with the exception of nitrogen. Total nitrogen content of the homogenized plant leaves were determined by total combustion in a Leco $\mathrm{N}$-analyzer (Leco Corp, Henderson, USA) (Sweeney and Rexroad, 1986). Nutrient concentrations in sample extracts were expressed in $\mathrm{mg} \mathrm{kg}^{-1}$.

\section{Non-Enzymatic Antioxidant Extraction}

The fresh leaf samples were taken from the freezer and lyophilized for $16 \mathrm{~h}$. at minus $86^{\circ} \mathrm{C}$ using the Vir-tis genesis freeze dryer (SP Industries, Gardiner, NY, 
USA). The lyophilized leaf samples were then homogenized into a fine powder using the micro plant grinder and stored in $2 \mathrm{~mL}$ vials at minus $40^{\circ} \mathrm{C}$. Then 20-25 mg of lyophilized plant samples were weighed into a $15 \mathrm{~mL}$ screw-cape tube and $5 \mathrm{~mL}$ of $70 \%$ methanol in nanopure water was used to extract plant samples as described in (Lapornik et al., 2005). The samples were then loaded on the Intelli-mixer RM2 rotator/mixer for $24 \mathrm{~h}$ (ELMI Ltd, Latvia) and centrifuged at $4000 \mathrm{rpm}$ for $5 \mathrm{~min}$ using the Eppendorf centrifuge 5810 R (Eppendorf, AG, Hamburg, Germany). The supernatant was then used directly for analysis after suitable dilution method was developed.

\section{Determination of Total Polyphenol Content}

Total polyphenols in plant extracts were determined by the Folin-Ciocalteu procedure as described by (Meyer et al., 1997). Total polyphenols were expressed in mg. $\mathrm{L}^{-1}$ Gallic Acid Equivalent (GAE).

\section{Determination of the Ferric Reducing Antioxidant Power (FRAP)}

The ferric reducing ability of the sample extracts were determined as described by (Benzie and Strain, 1996). The FRAP reagent was prepared by mixing 30 $\mathrm{mL}$ acetate buffer $\mathrm{pH} 3.6(300 \mathrm{mM}), 3 \mathrm{~mL}$ of $2,4,6$, tripyridyl-s-triazine (TPTZ) $(10 \mathrm{mM})$ prepared in $40 \mathrm{mM}$ hydrochloric acid, $3 \mathrm{~mL} \mathrm{FeCL}(20 \mathrm{mM})$ and $6.6 \mathrm{~mL}$ distilled water $\left(\mathrm{dH}_{2} \mathrm{O}\right) .10 \mu \mathrm{l}$ of sample was mixed with $300 \mu \mathrm{l}$ of FRAP reagent in a 96-well plate and incubated at $37^{\circ} \mathrm{C}$ for $30 \mathrm{~min}$. The change in absorbance due to the redox reaction occurring was monitored in a Thermo Scientific multiscan spectrum spectrophotometer (Thermo Fisher Scientific, Waltham, USA) at $593 \mathrm{~nm}$. FRAP were expressed in mg.L ${ }^{-1}$ Ascorbic Acid Equivalent (AAE).

\section{Determination of the Oxygen Radical Absorbance Capacity (ORAC)}

The oxygen radical absorbance capacities of plant extracts were determined as described by (Prior et al., 2003). The reaction is initiated by the thermal decomposition at $37^{\circ} \mathrm{C}$ of the azo-compound $2,2^{\prime}$-azobis (2-amidino-propane) dihydrochloride (AAPH) which serves as the source of peroxyl radicals. Control mixtures are then prepared using Trolox (6-hydroxy2,5,7,8-tetramethylchroman-2-carboxylic acid) solution. All reagents and standards were prepared in phosphate buffer (75 mM, pH 7.4). $138 \mu \mathrm{L}$ of fluorescence and 12 $\mu \mathrm{L}$ of the sample were mixed in a black Nunclon 96well plate. $50 \mu \mathrm{L}$ of AAPH was then added last to the plate and fluorescence readings were taken using a Thermo Scientific fluroskan ascent 2.5 plate reader (Thermo Fisher Scientific, Waltham, USA) at $485 \mathrm{~nm}$ and $583 \mathrm{~nm}$ respectively. Antioxidant activity was expressed in Trolox equivalents.

\section{Enzyme Extraction and Total Soluble Protein Determinations}

Enzyme extraction of plant samples were performed as described by (Zhou et al., 2004) with some modifications. The extraction buffer contained $25 \mathrm{mM}$ of 2-[4-(2-hydroxyethyl) piperazin-1-yl] ethane sulfonic acid (HEPES) at $\mathrm{pH} 7.8,0.2 \mathrm{mM}$ of Ethylenediaminetetraacetic Acid (EDTA), 2\% (w/v) polyvinylpyrrolidone (PVP), $1 \mathrm{~mL}$ of triton X-100 and $200 \mathrm{mM}$ of potassium chloride $(\mathrm{KCl})$ in $200 \mathrm{~mL}$ of nanopure water. Lyophilized samples weighing 30-35 mg were put into $15 \mathrm{ml}$ screw cap tubes and $2 \mathrm{~mL}$ of extraction buffer were added to each tube. The tubes were loaded on the Intelli-mixer RM2 rotator/mixer for a period of $17 \mathrm{hrs}$ allowing thorough homogenization. The homogenates were centrifuged for $20 \mathrm{~min}$ at $12000 \mathrm{rpm}$ and the supernatants obtained were used for enzyme analysis. All operations were performed between 0 - $4{ }^{\circ} \mathrm{C}$. An aliquot of each extract was used to determine total protein content using the Pierce Bicinchoninic Acid (BCA) protein assay kit according to the manufacturer's protocol (Scientific, 2011). The BCA protein assay is based on colorimetric detection and quantification of total protein. The working reagent was prepared by combining $50 \mathrm{~mL}$ of reagent $\mathrm{A}$ with $1 \mathrm{~mL}$ of $\mathrm{BCA}$ reagent $\mathrm{B}$ (50:1, Reagent A: B). $25 \mu \mathrm{L}$ of the homogenized extract were transferred in triplicates into microplate wells. Then $200 \mu \mathrm{l}$ of the working reagent was added to each well and plate was mixed thoroughly on a plate shaker for 30 seconds. The plate was covered and incubated at $37^{\circ} \mathrm{C}$ for $30 \mathrm{~min}$. The plate was then cooled to room temperature and the absorbance was measured $562 \mathrm{~nm}$ on a Thermo Scientific multiscan spectrum plate reader. $1 \mathrm{~mL}$ ampule of $2 \mathrm{mg} / \mathrm{mL}$ of Bovine Serum Albumin (BSA) was sufficient to prepare a set of known protein concentration standards which were assayed alongside the unknown homogenized extract.

\section{Determination of Superoxide Dismutase Activity}

Superoxide dismutase activity (SOD; EC 1.15.1.1) of plant extracts were determined as described in (Ellerby and Bredesen, 2000) with some modifications. $170 \mu \mathrm{L}$ of Diethylenetriaminepentaacetic Acid (DETAPAC) solution were added in triplicates to a visible 96-well plate. Then 12 $\mu \mathrm{L}$ of sample extract was added to each well with $18 \mu \mathrm{L}$ of SOD buffer $\left(50 \mathrm{mM}\right.$ of $\mathrm{NaPO}_{4}$-buffer at $\mathrm{pH} 7.4$ without triton X-100). Finally, $15 \mu \mathrm{L}$ of 6-Hydroxydopamine (6HD) was added to each well and immediately the autooxidation was recorded at $490 \mathrm{~nm}$ for 4 min with $1 \mathrm{~min}$ intervals. The activity of SOD was calculated from a linear calibration curve and SOD concentration was expressed as Units $\mathrm{mg}^{-1}$ of protein $\left(\mathrm{U} \mathrm{mg}^{-1}\right)$.

\section{Determination of Ascorbate Peroxidase Activity}

Ascorbate peroxidase (APX) (APX; EC 1.11.1.11) activity in plant extract was determined (Nakano and 
Asada, 1981) with some modifications. $180 \mu \mathrm{L}$ of 50 $\mathrm{mM} \mathrm{K}-\mathrm{PO}_{4}$ buffer (pH 7.0), $30 \mu \mathrm{L}$ of EDTA, $30 \mu \mathrm{L}$ of 5 $\mathrm{mM}$ ascorbate and $30 \mu \mathrm{L}$ of homogenized plant extract were added in triplicates to an ultraviolet 96 -well plate. The reaction was initiated by finally adding $30 \mu \mathrm{L}$ of 0.1 $\mathrm{mM}$ hydrogen peroxide $\left(\mathrm{H}_{2} \mathrm{O}_{2}\right)$ to each well and the reduction in ascorbate concentration was read by measuring the absorbance at $290 \mathrm{~nm}$ continuously for 180 seconds. The ascorbate oxidized was evaluated based on the extinction coefficient of ascorbate $(E)=2.8$ $\mathrm{mM}^{-1} \mathrm{~cm}^{-1}$ and the results expressed as APX units $\mathrm{mg}^{-1}$ of protein $\left(\mathrm{U}=1 \mathrm{mM}\right.$ of ascorbate oxidized per min at $\left.25^{\circ} \mathrm{C}\right)$.

\section{Determination of Guaiacol Peroxidase Activity}

Guaiacol peroxidase (GPX) activity (GPX; EC 1.11.1.7) was determined as described in (Bergmeyer et al., 1974) with some modifications. $180 \mu \mathrm{L}$ of $0.1 \mathrm{M}$ potassium phosphate buffer $\mathrm{KH}_{2} \mathrm{PO}_{4}(\mathrm{pH} 7.0), 30 \mu \mathrm{l}$ of guaiacol and $60 \mu \mathrm{l}$ of homogenized plant extract were added in triplicates to a visible 96 -well plate. The reaction was initiated by adding $30 \mu \mathrm{l}$ of $0.1 \mathrm{~mL}$ of $30 \%$ hydrogen peroxide $\left(\mathrm{H}_{2} \mathrm{O}_{2}\right)$ in $120 \mathrm{~mL}$ of nanopure water to each well and the rate of increase in absorbance at $436 \mathrm{~nm}$ was recorded using a linear portion of the curve with GPX activity expressed in Units $\mathrm{mg}^{-1}$ of protein $\left(\mathrm{U} \mathrm{mg}^{-1}\right)$.

\section{Lipid Extraction by Methyl-Tert-Butyl-Ether (MTBE)}

The accurate profiling of lipidomes were obtained by MTBE extraction which allows faster and cleaner lipid recovery as described by Matyash et al. (2008) with some modifications. $80-100 \mathrm{mg}$ of lyophilized plant homogenates were weighed into $15 \mathrm{~mL}$ screw cap tubes and $0.77 \mathrm{~mL}$ of methanol was added to each tube. The tubes were vortexed for $20 \mathrm{sec}$ and $2.56 \mathrm{~mL}$ of MTBE solvent was added to each tube. The tubes were loaded on the intelli-mixer RM2 rotator/mixer for $1 \mathrm{~h}$ at room temperature after which phase separation was induced by adding $0.64 \mathrm{~mL}$ of nanopure water. After $10 \mathrm{~min}$ of incubation at room temp, samples were centrifuged at $13,750 \mathrm{xg}$ for $4 \mathrm{~min}$ and the supernatant was removed with $2 \mathrm{~mL}$ disposable syringes and filtered using a 0.45 $\mu \mathrm{m}$ syringe filter. The filtrates were collected in $2 \mathrm{~mL}$ vials where 1-2 gm of sodium sulfite was added to each vial to remove all traces of water and a known concentration of $10 \mu \mathrm{L}$ of a mixture of PC 18:0/18:0, PE 17:0/17:0, Phosphatidylinositol (PI) 17:0/17:0, C24:1 $\beta$ d-galactosylceramide and diacylglycerol 16:0/18 were used as internal standard.

\section{Determination of Lipid Peroxidation (TBARS)}

Lipid peroxidation in the homogenized extract was determined in terms of Malondialdehyde (MDA) content by Thiobarbituric Acid Reaction (TBARS) as described by (Heath and Packer, 1968) with some modifications. $100 \mu \mathrm{l}$ of homogenized plant extract, $12.5 \mu \mathrm{l}$ of $4 \mathrm{mM}$ cold Butylated Hydroxytoluene (BHT) in ethanol and $100 \mu \mathrm{L}$ of $0.2 \mathrm{M}$ of orthophosphoric acid were mixed and vortexed for $10 \mathrm{sec}$ in $2 \mathrm{~mL}$ vials. Then $12.5 \mu \mathrm{L}$ of TBA reagent $(0.11 \mathrm{M}$ in $0.1 \mathrm{M} \mathrm{NaOH})$ was added to each vial and vortexed for another $10 \mathrm{sec}$. The vials were heated at $90^{\circ} \mathrm{C}$ for one $1 \mathrm{~h}$ and cooled on ice for two min with further cooling at room temp for $5 \mathrm{~min}$. $1000 \mu \mathrm{L}$ of n-butanol with $100 \mu \mathrm{L}$ of saturated $\mathrm{NaCl}$ were added to the vials for better phase separation. The vials were then centrifuged at $12,000 \mathrm{rpm}$ for $2 \mathrm{~min}$ at $4^{\circ} \mathrm{C}$ then $300 \mu \mathrm{L}$ from each vial was put in triplicates into a visible 96well plate. MDA equivalent was calculated from the difference in absorbance at 532 and $572 \mathrm{~nm}$ using extinction coefficient of $155 \mathrm{mM}^{-1} \mathrm{~cm}^{-1}$.

\section{Gas Chromatographic Profiling of Lipidomes}

The lipid profile of the plant sample extracts was determined using the Agilent 6890 gas chromatographic mass selective detector (Agilent Technologies, Little Falls, DE, USA). and the method used to profile the lipids was developed from EPA method 551 (Hodgeson and Cohen, 1990). The initial oven temperature at 0.00 min was $70^{\circ} \mathrm{C}$ to reach a maximum temperature of $320^{\circ} \mathrm{C}$ at $0.25 \mathrm{~min}$. The total runtime was $43.25 \mathrm{~min}$ per sample and the injector front inlet mode was splitless with initial temperature at $280^{\circ} \mathrm{C}$ and pressure at 60.2 $\mathrm{kPa}$. The purge flow was $30 \mathrm{~mL} / \mathrm{min}$ with a purge time of $3 \mathrm{~min}$ and a total flow of $33.8 \mathrm{~mL} / \mathrm{min}$ with an injection volume of $1 \mu \mathrm{L}$ and helium as the carrier gas. The capillary column used was model ZB 274305 (Phenomenex, Torrance, CA, USA) mainly used for semi volatiles with a nominal length of $30.0 \mathrm{~m} \times 250 \mu \mathrm{m}$ (diameter) $\times 0.25 \mu \mathrm{m}$ (film thickness). The GC transfer line was maintained at $280^{\circ} \mathrm{C}$ with the mass selective detector operated at EMV mode and the resulting EM voltage to be 1800 with a maximum source temperature of $250^{\circ} \mathrm{C}$ and a solvent delay of $6 \mathrm{~min}$. A tentative identification of the compounds was performed based on the comparison of their relative retention time and mass spectra with those of the WILEY229 library data of the GC/MS system and published data.

\section{Statistical Analysis of Data}

All values reported in this study are means of four replicates. The data were Analyzed by two-way Analysis of Variance (ANOVA) and compared at $\mathrm{P} \leq 0.05$ significance level by the Scheffe test using Statistical Analysis System (SAS). Below are tables reporting the significance of the two main factors and their interactions for both experiments.

\section{Results}

Effect of Trihalomethane Halogenation and Concentration on Nutrient Levels

After 30 days of single exposure to each trihalomethane chemical and halogenation kept at a constant, six of the twelve nutrients decreased 
significantly at $\mathrm{P} \leq 0.05$ with increasing trihalomethane concentration in both tomato cultivars. These nutrients include Nitrogen $(\mathrm{N})$, potassium $(\mathrm{k})$, Manganese $(\mathrm{Mn})$, Copper (Cu), Zinc (Zn) and Boron (B) (Table 1).

Table 1: Effects of trihalomethane concentration and trihalomethane chemical species on nutrient concentrations of the dry matter yields of tomato plants (30 days treatment data)

\begin{tabular}{|c|c|c|c|c|c|c|c|}
\hline \multicolumn{8}{|c|}{ Concentration mg. $\mathrm{L}^{-1}$} \\
\hline Nutrients mg kg ${ }^{-1}$ & Chemical species & 0 control & $2.5 \mathrm{mg} . \mathrm{L}^{-1}$ & $5.0 \mathrm{mg} . \mathrm{L}^{-1}$ & $7.5 \mathrm{mg} . \mathrm{L}^{-1}$ & $10 \mathrm{mg} \cdot \mathrm{L}^{-1}$ & Mean chem. Species \\
\hline \multirow[t]{8}{*}{$\mathrm{N}$} & $\mathrm{CHBr}_{2} \mathrm{Cl}$ & 3.140 & 2.993 & 2.788 & 2.508 & 2.023 & 2.690 \\
\hline & $\mathrm{CHBrCl}_{2}$ & 1.935 & 1.925 & 1.770 & 1.640 & 1.433 & 1.741 \\
\hline & $\mathrm{CHBr}_{3}$ & 1.985 & 1.530 & 1.275 & 1.143 & 1.088 & 1.404 \\
\hline & $\mathrm{CHCl}_{3}$ & 1.278 & 1.278 & 1.085 & 1.015 & 0.900 & 1.111 \\
\hline & Mean Conc. & 2.085 & 1.932 & 1.730 & 1.577 & 1.361 & \\
\hline & CV\% & & & $1.93 \%$ & & & \\
\hline & $\mathrm{P} \leq 0.05$ & & & $*$ & & & $*$ \\
\hline & Interaction & & & NS & & & \\
\hline \multirow[t]{8}{*}{$\mathrm{P}$} & $\mathrm{CHBr}_{2} \mathrm{Cl}$ & 0.940 & 0.859 & 0.845 & 0.790 & 0.790 & 0.845 \\
\hline & $\mathrm{CHBrCl}_{2}$ & 0.888 & 0.765 & 0.730 & 0.613 & 0.563 & 0.712 \\
\hline & $\mathrm{CHBr}_{3}$ & 0.670 & 0.653 & 0.603 & 0.593 & 0.420 & 0.588 \\
\hline & $\mathrm{CHCl}_{3}$ & 0.583 & 0.568 & 0.518 & 0.425 & 0.395 & 0.498 \\
\hline & Mean Conc. & 0.770 & 0.711 & 0.674 & 0.605 & 0.542 & \\
\hline & CV\% & & & $1.88 \%$ & & & \\
\hline & $\mathrm{P} \leq 0.05$ & & & NS & & & $*$ \\
\hline & Interaction & & & $*$ & & & \\
\hline \multirow[t]{8}{*}{ K } & $\mathrm{CHBR}_{2} \mathrm{Cl}$ & 10.335 & 9.945 & 8.045 & 7.918 & 7.383 & 8.725 \\
\hline & $\mathrm{CHBRCl}_{2}$ & 9.778 & 7.090 & 6.603 & 4.458 & 4.453 & 6.476 \\
\hline & $\mathrm{CHBr}_{3}$ & 5.385 & 4.285 & 4.243 & 3.663 & 2.340 & 3.983 \\
\hline & $\mathrm{CHCl}_{3}$ & 3.745 & 3.700 & 2.913 & 2.650 & 2.488 & 3.099 \\
\hline & Mean Conc. & 7.311 & 6.255 & 5.451 & 4.672 & 4.166 & \\
\hline & CV\% & & & $2.92 \%$ & & & \\
\hline & $\mathrm{P} \leq 0.05$ & & & $*$ & & & $*$ \\
\hline & Interaction & & & $*$ & & & \\
\hline \multirow[t]{8}{*}{$\mathrm{Ca}$} & $\mathrm{CHBr}_{2} \mathrm{Cl}$ & 1.553 & 1.405 & 1.410 & 1.508 & 1.465 & 1.468 \\
\hline & $\mathrm{CHBrCl}_{2}$ & 1.355 & 1.253 & 1.740 & 1.760 & 1.355 & 1.493 \\
\hline & $\mathrm{CHBr}_{3}$ & 1.383 & 1.205 & 1.795 & 1.680 & 1.193 & 1.451 \\
\hline & $\mathrm{CHCl}_{3}$ & 1.735 & 1.220 & 1.145 & 1.160 & 1.320 & 1.316 \\
\hline & Mean Conc. & 1.506 & 1.271 & 1.523 & 1.527 & 1.333 & \\
\hline & CV\% & & & $2.10 \%$ & & & \\
\hline & $\mathrm{P} \leq 0.05$ & & & NS & & & NS \\
\hline & Interaction & & & $*$ & & & \\
\hline \multirow[t]{8}{*}{$\mathrm{Mg}$} & $\mathrm{CHBr}_{2} \mathrm{Cl}$ & 0.340 & 0.300 & 0.285 & 0.288 & 0.283 & 0.299 \\
\hline & $\mathrm{CHBrCl}_{2}$ & 0.343 & 0.290 & 0.333 & 0.350 & 0.295 & 0.322 \\
\hline & $\mathrm{CHBr}_{3}$ & 0.335 & 0.270 & 0.315 & 0.293 & 0.223 & 0.287 \\
\hline & $\mathrm{CHCl}_{3}$ & 0.323 & 0.253 & 0.223 & 0.260 & 0.228 & 0.257 \\
\hline & Mean Conc. & 0.335 & 0.278 & 0.289 & 0.298 & 0.257 & \\
\hline & CV\% & & & $1.68 \%$ & & & \\
\hline & $\mathrm{P} \leq 0.05$ & & & NS & & & $*$ \\
\hline & Interaction & & & NS & & & \\
\hline \multirow[t]{8}{*}{ S } & $\mathrm{CHBr}_{2} \mathrm{Cl}$ & 0.698 & 0.650 & 0.615 & 0.550 & 0.543 & 0.611 \\
\hline & $\mathrm{CHBrCl}_{2}$ & 0.570 & 0.465 & 0.418 & 0.400 & 0.370 & 0.445 \\
\hline & $\mathrm{CHBr}_{3}$ & 0.445 & 0.335 & 0.303 & 0.283 & 0.280 & 0.329 \\
\hline & $\mathrm{CHCl}_{3}$ & 0.395 & 0.326 & 0.280 & 0.253 & 0.243 & 0.299 \\
\hline & Mean Conc. & 0.527 & 0.444 & 0.404 & 0.372 & 0.359 & \\
\hline & CV\% & & & $2.71 \%$ & & & \\
\hline & $\mathrm{P} \leq 0.05$ & & & NS & & & $*$ \\
\hline & Interaction & & & NS & & & \\
\hline \multirow[t]{5}{*}{$\mathrm{Na}$} & $\mathrm{CHBr}_{2} \mathrm{Cl}$ & 857.50 & 804.75 & 1023.75 & 1016.50 & 812.25 & 902.95 \\
\hline & $\mathrm{CHBrCl}_{2}$ & 1101.0 & 900.25 & 1152.75 & 1253.50 & 1019.50 & 1085.40 \\
\hline & $\mathrm{CHBr}_{3}$ & 1161.2 & 841.25 & 1120.00 & 886.00 & 780.00 & 957.70 \\
\hline & $\mathrm{CHCl}_{3}$ & 911.75 & 617.75 & 1032.00 & 892.25 & 758.75 & 842.50 \\
\hline & Mean Conc. & 1007.88 & 791.00 & 1082.13 & 1012.06 & 842.63 & \\
\hline
\end{tabular}


Table 1: Continue

\begin{tabular}{|c|c|c|c|c|c|c|c|}
\hline & CV\% & & & $2.31 \%$ & & & \\
\hline & $\mathrm{P} \leq 0.05$ & & & NS & & & * \\
\hline & Interaction & & & NS & & & \\
\hline \multirow[t]{8}{*}{$\mathrm{Mn}$} & $\mathrm{CHBr}_{2} \mathrm{Cl}$ & 61.50 & 58.50 & 50.50 & 42.50 & 26.25 & 47.85 \\
\hline & $\mathrm{CHBrCl}_{2}$ & 44.25 & 43.00 & 38.00 & 31.75 & 28.75 & 37.15 \\
\hline & $\mathrm{CHBr}_{3}$ & 52.50 & 38.75 & 36.00 & 34.75 & 27.00 & 37.80 \\
\hline & $\mathrm{CHCl}_{3}$ & 50.25 & 42.75 & 41.00 & 35.50 & 33.25 & 40.55 \\
\hline & Mean Conc. & 52.125 & 45.750 & 41.375 & 36.125 & 28.813 & \\
\hline & CV\% & & & $2.36 \%$ & & & \\
\hline & $\mathrm{P} \leq 0.05$ & & & $*$ & & & $*$ \\
\hline & Interaction & & & * & & & \\
\hline \multirow[t]{8}{*}{$\mathrm{Fe}$} & $\mathrm{CHBr}_{2} \mathrm{Cl}$ & 1224.75 & 789.50 & 1251.25 & 1105.50 & 1105.50 & 1095.30 \\
\hline & $\mathrm{CHBrCl}_{2}$ & 1603.50 & 847.50 & 507.25 & 966.25 & 971.50 & 979.20 \\
\hline & $\mathrm{CHBr}_{3}$ & 3040.25 & 931.00 & 2352.75 & 1429.00 & 1492.50 & 1849.10 \\
\hline & $\mathrm{CHCl}_{3}$ & 988.75 & 1465.25 & 3072.75 & 2634.00 & 2387.50 & 2109.65 \\
\hline & Mean Conc. & 1714.31 & 1008.31 & 1796.00 & 1533.69 & 1489.25 & \\
\hline & CV\% & & & $10.79 \%$ & & & \\
\hline & $\mathrm{P} \leq 0.05$ & & & NS & & & NS \\
\hline & Interaction & & & NS & & & \\
\hline \multirow[t]{8}{*}{$\mathrm{Cu}$} & $\mathrm{CHBr}_{2} \mathrm{Cl}$ & 9.25 & 8.75 & 8.25 & 8.00 & 7.50 & 8.35 \\
\hline & $\mathrm{CHBrCl}_{2}$ & 7.75 & 6.75 & 6.50 & 6.25 & 6.00 & 6.65 \\
\hline & $\mathrm{CHBr}_{3}$ & 8.50 & 7.75 & 5.75 & 5.25 & 4.75 & 6.40 \\
\hline & $\mathrm{CHCl}_{3}$ & 7.00 & 6.75 & 6.50 & 5.25 & 4.00 & 5.90 \\
\hline & Mean Conc. & 8.125 & 7.500 & 6.750 & 6.188 & 5.563 & \\
\hline & CV\% & & & $2.35 \%$ & & & \\
\hline & $\mathrm{P} \leq 0.05$ & & & $*$ & & & * \\
\hline & Interaction & & & NS & & & \\
\hline \multirow[t]{8}{*}{$\mathrm{Zn}$} & $\mathrm{CHBr}_{2} \mathrm{Cl}$ & 217.25 & 176.00 & 166.75 & 155.00 & 145.25 & 172.05 \\
\hline & $\mathrm{CHBrCl}_{2}$ & 188.25 & 182.00 & 132.25 & 126.75 & 111.00 & 148.05 \\
\hline & $\mathrm{CHBr}_{3}$ & 197.25 & 183.25 & 174.00 & 145.25 & 108.75 & 161.70 \\
\hline & $\mathrm{CHCl}_{3}$ & 154.25 & 146.50 & 140.75 & 134.25 & 89.50 & 133.05 \\
\hline & Mean Conc. & 189.25 & 171.875 & 153.438 & 140.313 & 113.625 & \\
\hline & CV\% & & & $2.85 \%$ & & & \\
\hline & $\mathrm{P} \leq 0.05$ & & & $*$ & & & $*$ \\
\hline & Interaction & & & NS & & & \\
\hline \multirow[t]{7}{*}{ B } & $\mathrm{CHBr}_{2} \mathrm{Cl}$ & 40.00 & 36.00 & 33.50 & 32.50 & 31.75 & 34.75 \\
\hline & $\mathrm{CHBrCl}_{2}$ & 39.75 & 35.75 & 31.25 & 27.25 & 27.25 & 32.25 \\
\hline & $\mathrm{CHBr}_{3}$ & 31.25 & 25.50 & 25.00 & 22.75 & 20.75 & 25.05 \\
\hline & $\mathrm{CHCl}_{3}$ & 25.50 & 23.00 & 23.00 & 20.00 & 19.25 & 22.15 \\
\hline & Mean Conc. & 34.125 & 30.063 & 28.188 & 25.625 & 24.75 & \\
\hline & $\mathrm{P}<0.05$ & & & $\begin{array}{l}1.68 \% 0 \\
*\end{array}$ & & & * \\
\hline & Interaction & & & NS & & & \\
\hline
\end{tabular}

Values presented are the mean values calculated from the sum of both TMM = tomato moneymaker and TS $=$ tomato star means divided by $\mathrm{n}=2$ each with $\mathrm{n}=4$ replicates, $*=$ significance at $\mathrm{P} \leq 0.05$ respectively; $\mathrm{NS}=$ not significant, $\mathrm{CHBrCl}_{2}=$ Bromodichloromethane, $\mathrm{CHBr}_{3}=$ Bromoform, $\mathrm{CHCl}_{3}=$ Chloroform, $\mathrm{CHBr}_{2} \mathrm{Cl}=$ Dibromochloromethane

The average percentage decrease in nutrient levels from control plants to those exposed to $10 \mathrm{mg} . \mathrm{L}^{-1}$ of trihalomethanes were $\mathrm{N}(34.72 \%), \mathrm{K}(43.02 \%), \mathrm{Mn}$ (44.72\%), $\mathrm{Cu}$ (31.53\%), Zn (39.96\%) and B (27.47\%). The nutrient levels of $\mathrm{N}, \mathrm{P}, \mathrm{K}, \mathrm{S}, \mathrm{Cu}, \mathrm{Zn}$ and $\mathrm{B}$ in plant dry matter decreased significantly at $\mathrm{P} \leq 0.05$ with increasing chlorine of the trihalomethane molecules (except for $\mathrm{CHBr}_{3}$ ) at a constant concentration of $10 \mathrm{mg} . \mathrm{L}^{-1}$ in the order of $\mathrm{CHBr}_{2} \mathrm{Cl}>\mathrm{CHBrCl}_{2}>\mathrm{CHBr}_{3}>\mathrm{CHCl}_{3}$ in the tomato cultivars (Table 2).

It should be noted that the nutrients $\mathrm{Cu}$ and $\mathrm{Zn}$ displayed these trends only in the TMM cultivar. The average percentage decrease in nutrient levels from the effects of mono-chlorinated to the tri-chlorinated trihalomethanes was N (58.70\%), P (41.07\%), K (64.48\%), $\mathrm{S}(51.06 \%), \mathrm{Cu}(29.34 \%), \mathrm{Zn}(22.67 \%)$ and B (36.26\%).

The nutrients levels affected by both the effects of increasing halogenation and concentration of trihalomethanes in both tomato cultivars tested can be seen in Fig. 1.

A Comparison between the effects of increasing trihalomethane concentration and the effects of increasing chlorination on the percentage decrease in nutrient levels can be seen in Fig. 2. The effects of increasing halogenation induced a greater decrease on nutrient levels with the exception of copper and zinc where the effects of increasing trihalomethane dose appear to be greater. 
Table 2: Effects of trihalomethane chemical species at a concentration of $10 \mathrm{mgL}^{-1}$ on plants nutrient concentration of the dry matter yields of the tomato cultivars (30 days treatment data)

\begin{tabular}{|c|c|c|c|c|c|c|}
\hline $\begin{array}{l}\text { Chemical species } \\
\text { Nutrients } \mathrm{mg} \mathrm{kg}^{-1}\end{array}$ & Plant Varieties & $\mathrm{CHBr}_{2} \mathrm{Cl}$ & $\mathrm{CHBrCl}_{2}$ & $\mathrm{CHBr}_{3}$ & $\mathrm{CHCl}_{3}$ & Mean $p$ varieties \\
\hline \multirow[t]{6}{*}{$\mathrm{N}$} & TMM & 2.840 & 1.727 & 1.263 & 0.993 & 1.706 \\
\hline & $\mathrm{TS}$ & 2.540 & 1.754 & 1.545 & 1.229 & 1.767 \\
\hline & Mean $\mathrm{C}$ varieties & 2.690 & 1.741 & 1.404 & 1.111 & \\
\hline & CV\% & & & $1.93 \%$ & & \\
\hline & $\mathrm{P} \leq 0.05$ & & & $*$ & & NS \\
\hline & Interaction & & & $*$ & & \\
\hline \multirow[t]{6}{*}{$\mathrm{P}$} & TMM & 0.836 & 0.710 & 0.543 & 0.461 & 0.638 \\
\hline & TS & 0.853 & 0.713 & 0.632 & 0.534 & 0.683 \\
\hline & Mean $\mathrm{C}$ varieties & 0.845 & 0.712 & 0.588 & 0.498 & \\
\hline & $\mathrm{CV} \%$ & & & $1.88 \%$ & & \\
\hline & $\mathrm{P} \leq 0.05$ & & & * & & NS \\
\hline & Interaction & & & NS & & \\
\hline \multirow[t]{6}{*}{ K } & TMM & 9.951 & 6.617 & 3.906 & 2.855 & 5.832 \\
\hline & TS & 7.499 & 6.335 & 4.060 & 3.343 & 5.309 \\
\hline & Mean $\mathrm{C}$ varieties & 8.725 & 6.476 & 3.983 & 3.099 & \\
\hline & CV\% & & & $2.92 \%$ & & \\
\hline & $\mathrm{P} \leq 0.05$ & & & $*$ & & NS \\
\hline & Interaction & & & $*$ & & \\
\hline \multirow[t]{6}{*}{$\mathrm{Ca}$} & TMM & 1.525 & 1.546 & 1.493 & 1.312 & 1.469 \\
\hline & TS & 1.411 & 1.439 & 1.409 & 1.320 & 1.395 \\
\hline & Mean $\mathrm{C}$ varieties & 1.468 & 1.493 & 1.451 & 1.316 & \\
\hline & CV\% & & & $2.10 \%$ & & \\
\hline & $\mathrm{P} \leq 0.05$ & & & NS & & NS \\
\hline & Interaction & & & NS & & \\
\hline \multirow[t]{6}{*}{$\mathrm{Mg}$} & TMM & 0.285 & 0.323 & 0.287 & 0.248 & 0.286 \\
\hline & TS & 0.313 & 0.321 & 0.287 & 0.266 & 0.297 \\
\hline & Mean $C$ varieties & 0.299 & 0.322 & 0.287 & 0.257 & \\
\hline & $\mathrm{CV} \%$ & & & $1.68 \%$ & & \\
\hline & $\mathrm{P} \leq 0.05$ & & & NS & & NS \\
\hline & Interaction & & & NS & & \\
\hline \multirow[t]{6}{*}{ S } & TMM & 0.656 & 0.477 & 0.317 & 0.282 & 0.433 \\
\hline & TS & 0.566 & 0.412 & 0.341 & 0.315 & 0.409 \\
\hline & Mean $C$ varieties & 0.611 & 0.445 & 0.329 & 0.299 & \\
\hline & CV\% & & & $2.71 \%$ & & \\
\hline & $\mathrm{P} \leq 0.05$ & & & $*$ & & NS \\
\hline & Interaction & & & NS & & \\
\hline \multirow[t]{6}{*}{$\mathrm{Na}$} & TMM & 946.2 & 1248.9 & 932.6 & 802.0 & 982.425 \\
\hline & $\mathrm{TS}$ & 859.7 & 921.9 & 982.8 & 883.0 & 911.850 \\
\hline & Mean $\mathrm{C}$ varieties & 902.95 & 1085.40 & 957.70 & 842.50 & \\
\hline & CV\% & & & $2.31 \%$ & & \\
\hline & $\mathrm{P} \leq 0.05$ & & & NS & & NS \\
\hline & Interaction & & & $*$ & & \\
\hline \multirow[t]{6}{*}{$\mathrm{Mn}$} & TMM & 56.8 & 40.8 & 35.5 & 38.7 & 42.950 \\
\hline & TS & 38.9 & 33.5 & 40.1 & 42.4 & 38.725 \\
\hline & Mean $\mathrm{C}$ varieties & 47.85 & 37.15 & 37.80 & 40.55 & \\
\hline & CV\% & & & $2.36 \%$ & & \\
\hline & $\mathrm{P} \leq 0.05$ & & & NS & & NS \\
\hline & Interaction & & & $*$ & & \\
\hline \multirow[t]{6}{*}{$\mathrm{Fe}$} & TMM & 1081.4 & 1192.0 & 1148.8 & 1779.3 & 1300.38 \\
\hline & TS & 1109.2 & 766.4 & 2549.4 & 2440.0 & 1716.25 \\
\hline & Mean $\mathrm{C}$ varieties & 1095.30 & 979.20 & 1849.10 & 2109.65 & \\
\hline & $\mathrm{CV} \%$ & & & $10.79 \%$ & & \\
\hline & $\mathrm{P} \leq 0.05$ & & & NS & & NS \\
\hline & Interaction & & & NS & & \\
\hline $\mathrm{Cu}$ & TMM & 8.9 & 7.2 & 5.8 & 4.8 & 6.675 \\
\hline
\end{tabular}




\begin{tabular}{|c|c|c|c|c|c|c|}
\hline & TS & 7.8 & 6.1 & 7.0 & 7.0 & 6.975 \\
\hline & Mean $\mathrm{C}$ varieties & 8.35 & 6.65 & 6.40 & 5.90 & \\
\hline & CV\% & & & $2.35 \%$ & & \\
\hline & $\mathrm{P} \leq 0.05$ & & & $*$ & & NS \\
\hline & Interaction & & & $*$ & & \\
\hline \multirow[t]{6}{*}{$\mathrm{Zn}$} & TMM & 193.8 & 160.5 & 147.3 & 126.0 & 156.900 \\
\hline & $\mathrm{TS}$ & 150.3 & 135.6 & 176.1 & 140.1 & 150.525 \\
\hline & Mean $C$ varieties & 172.05 & 148.05 & 161.70 & 133.05 & \\
\hline & CV\% & & & $2.85 \%$ & & \\
\hline & $\mathrm{P} \leq 0.05$ & & & $*$ & & NS \\
\hline & Interaction & & & $*$ & & \\
\hline \multirow[t]{6}{*}{ B } & TMM & 37.6 & 33.6 & 26.1 & 22.2 & 29.875 \\
\hline & $\mathrm{TS}$ & 31.9 & 30.9 & 24.0 & 22.1 & 27.225 \\
\hline & Mean $C$ varieties & 34.75 & 32.25 & 25.05 & 22.15 & \\
\hline & CV\% & & & $1.68 \%$ & & \\
\hline & $\mathrm{P} \leq 0.05$ & & & $*$ & & $*$ \\
\hline & Interaction & & & NS & & \\
\hline
\end{tabular}

Values presented are means of $\mathrm{n}=4$ replicates, $*=$ effect of trihalomethanes significant at $\mathrm{P} \leq 0.05$ respectively; NS $=$ not significant, $\mathrm{TMM}=$ tomato moneymaker, $\mathrm{TS}=$ tomato star, $\mathrm{CHBrCl}_{2}=$ Bromodichloromethane, $\mathrm{CHBr}_{3}=$ Bromoform, $\mathrm{CHCl}_{3}=\mathrm{Chloroform}_{\text {, }}$ $\mathrm{CHBr}_{2} \mathrm{Cl}=$ Dibromochloromethane

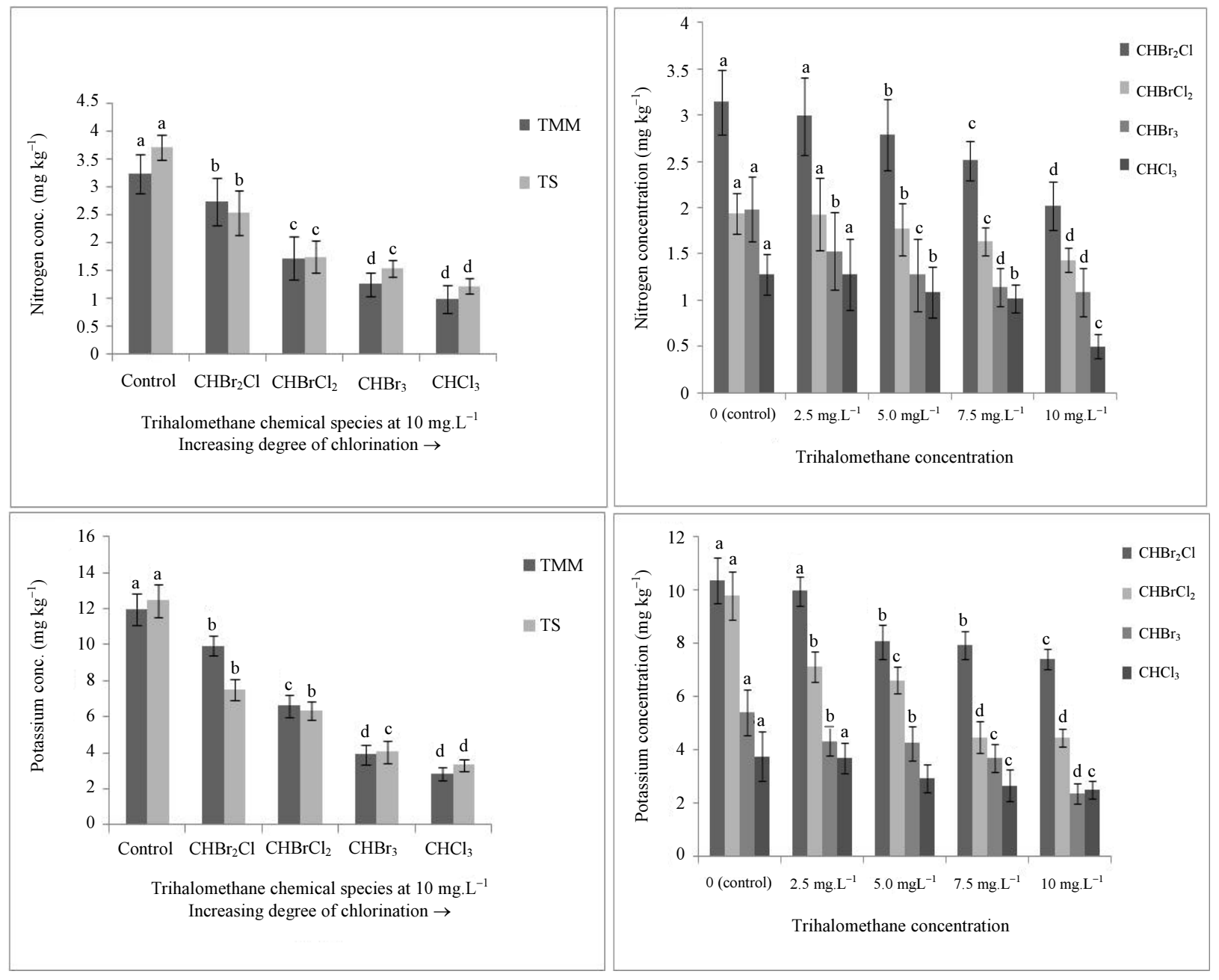




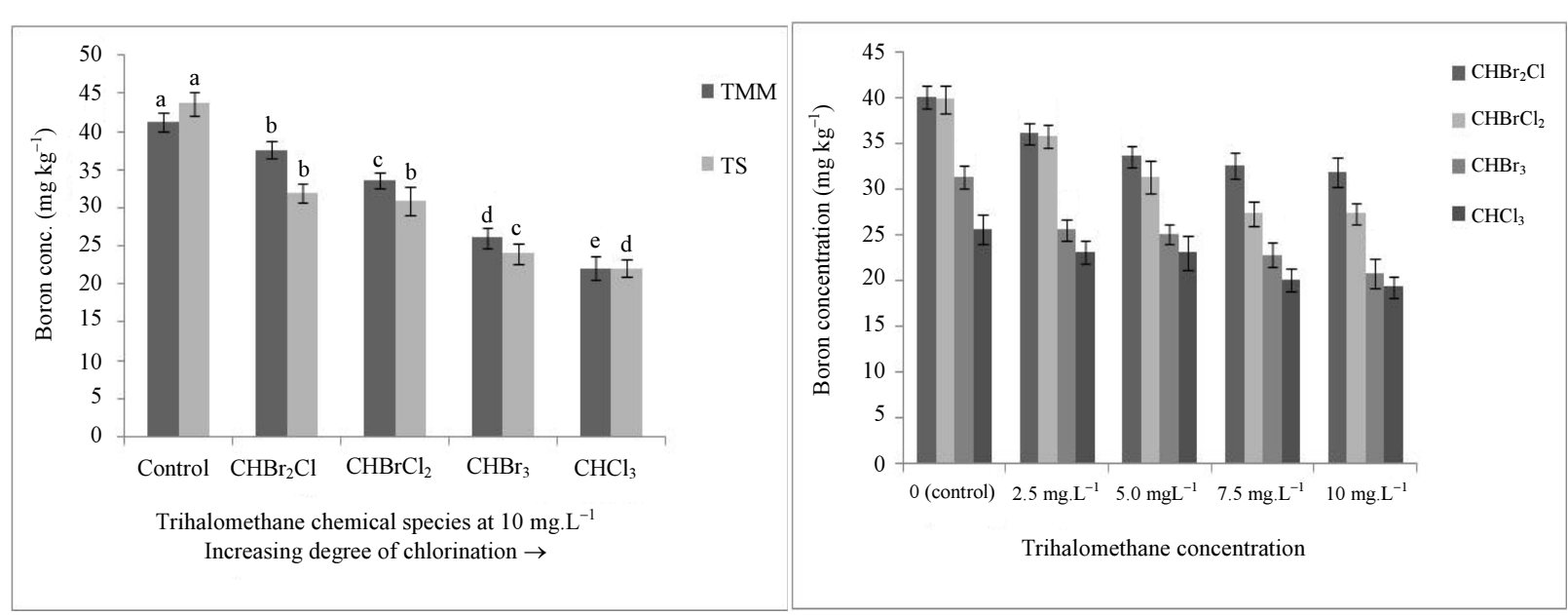

Fig. 1: Effects of increasing trihalomethane halogenation and concentration on the nutrient levels of the dry matter yields of both tomato cultivars. Control plants were exposed to deionized water containing plant nutrients only. Means followed by similar letter in a column are not significantly different from each other at $\mathrm{P} \leq 0.05$ according to FSD. Vertical bars represent standard error of means $(n=4)$. Mean values from the same cultivar and the same chemical treatment were compared with each other only; Values presented in the concentration graphs are the mean values calculated from the sum of both TMM = tomato moneymaker and TS $=$ tomato star means divided by $n=2$ each with $n=4$ replicates

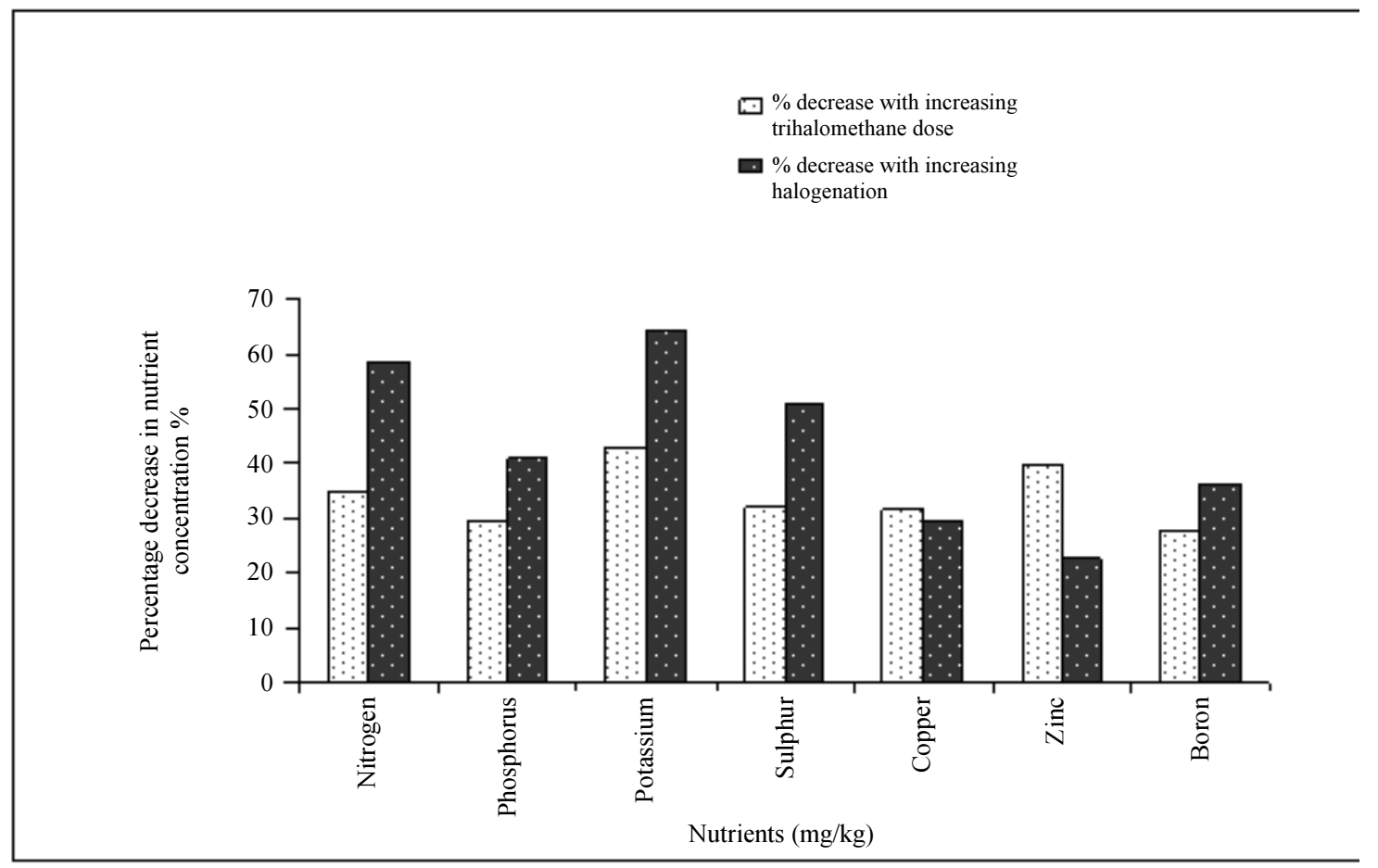

Fig. 2: Comparison between the effects of increasing trihalomethane dose and increasing halogenation on nutrient concentration of the dry matter of tomato plants after a 30 day exposure

Effects of Trihalomethane Halogenation And Concentration on Non-Enzymatic and Enzymatic Biomarkers of Oxidative Stress

Antioxidant parameters that increased significantly at $\mathrm{P} \leq 0.05$ with increasing trihalomethane concentration and halogenation kept at a constant include total polyphenols, Ferric Reducing Antioxidant Power (FRAP), Oxygen Radical Absorbance Capacity (ORAC), peroxidase enzyme activities (APX and GPX) and thiobarbituric acid reacting substances (TBARS) in both tomato cultivars (Table 3). 
Table 3: Effects of trihalomethane concentration and trihalomethane chemical species on non-enzymatic and enzymatic biomarkers of oxidative stress in lyophilized leaf tissues of tomato plants (30 days treatment data)

Trihalomethane Concentration mg. $\mathrm{L}^{-1}$

\begin{tabular}{|c|c|c|c|c|c|c|c|}
\hline & Chemical species & 0 control & $2.5 \mathrm{mg} \cdot \mathrm{L}^{-1}$ & $5.0 \mathrm{mg} . \mathrm{L}^{-1}$ & $7.5 \mathrm{mg} . \mathrm{L}^{-1}$ & $10 \mathrm{mg} \cdot \mathrm{L}^{-1}$ & Mean chem. species \\
\hline \multirow{8}{*}{$\begin{array}{l}\text { Polyphenols } \\
\text { mg.L } L^{-1} \text { (GAE) }\end{array}$} & $\mathrm{CHBr}_{2} \mathrm{Cl}$ & 2.361 & 3.665 & 3.907 & 3.958 & 4.285 & 3.635 \\
\hline & $\mathrm{CHBrCl}_{2}$ & 5.284 & 6.805 & 6.875 & 7.491 & 9.103 & 7.112 \\
\hline & $\mathrm{CHBr}_{3}$ & 9.590 & 11.625 & 11.824 & 12.216 & 15.200 & 12.091 \\
\hline & $\mathrm{CHCl}_{3}$ & 15.096 & 15.324 & 16.363 & 17.008 & 18.224 & 16.403 \\
\hline & Mean Conc. & 8.083 & 9.355 & 9.742 & 10.168 & 11.703 & \\
\hline & $\mathrm{CV} \%$ & & $3.05 \%$ & & & & \\
\hline & $\mathrm{P} \leq 0.05$ & & * & & & & * \\
\hline & Interaction & & NS & & & & \\
\hline \multirow{8}{*}{$\begin{array}{l}\text { FRAP } \\
\text { mg.L }{ }^{-1}(\mathrm{AAE})\end{array}$} & $\mathrm{CHBr}_{2} \mathrm{Cl}$ & 14.707 & 21.743 & 21.971 & 22.086 & 23.348 & 20.771 \\
\hline & $\mathrm{CHBrCl}_{2}$ & 20.777 & 26.567 & 33.505 & 34.737 & 37.131 & 30.543 \\
\hline & $\mathrm{CHBr}_{3}$ & 31.537 & 32.181 & 34.616 & 42.827 & 48.107 & 37.853 \\
\hline & $\mathrm{CHCl}_{3}$ & 36.824 & 39.927 & 40.502 & 44.988 & 52.903 & 43.029 \\
\hline & Mean Conc. & 25.961 & 30.105 & 32.649 & 36.160 & 40.372 & \\
\hline & CV\% & & $2.93 \%$ & & & & \\
\hline & $\mathrm{P} \leq 0.05$ & & * & & & & * \\
\hline & Interaction & & $*$ & & & & \\
\hline \multirow{8}{*}{$\begin{array}{l}\text { ORAC } \\
\text { mM trolox }\end{array}$} & $\mathrm{CHBr}_{2} \mathrm{Cl}$ & 3.718 & 6.853 & 7.189 & 7.645 & 8.002 & 6.681 \\
\hline & $\mathrm{CHBrCl}_{2}$ & 7.565 & 10.912 & 11.100 & 11.275 & 12.404 & 10.651 \\
\hline & $\mathrm{CHBr}_{3}$ & 7.117 & 7.133 & 7.932 & 9.279 & 11.238 & 8.540 \\
\hline & $\mathrm{CHCl}_{3}$ & 18.852 & 21.680 & 21.971 & 28.717 & 32.102 & 24.665 \\
\hline & Mean Conc. & 9.313 & 9.931 & 12.048 & 14.229 & 15.937 & \\
\hline & CV\% & & $3.28 \%$ & & & & \\
\hline & $\mathrm{P} \leq 0.05$ & & $*$ & & & & * \\
\hline & Interaction & & $*$ & & & & \\
\hline \multirow{8}{*}{$\begin{array}{l}\text { APX activity } \\
\mathrm{U} \mathrm{mg}^{-1}\end{array}$} & $\mathrm{CHBr}_{2} \mathrm{Cl}$ & 0.001 & 0.004 & 0.005 & 0.006 & 0.007 & 0.004 \\
\hline & $\mathrm{CHBrCl}_{2}$ & 0.007 & 0.008 & 0.011 & 0.020 & 0.026 & 0.014 \\
\hline & $\mathrm{CHBr}_{3}$ & 0.002 & 0.002 & 0.002 & 0.003 & 0.004 & 0.002 \\
\hline & $\mathrm{CHCl}_{3}$ & 0.012 & 0.022 & 0.023 & 0.031 & 0.076 & 0.033 \\
\hline & Mean Conc. & 0.006 & 0.009 & 0.010 & 0.011 & 0.028 & \\
\hline & CV\% & & $24.54 \%$ & & & & \\
\hline & $\mathrm{P} \leq 0.05$ & & $*$ & & & & * \\
\hline & Interaction & & NS & & & & \\
\hline \multirow{8}{*}{$\begin{array}{l}\text { GPX activity } \\
\mathrm{U} \mathrm{mg}^{-1}\end{array}$} & $\mathrm{CHBr}_{2} \mathrm{Cl}$ & 0.005 & 0.009 & 0.011 & 0.012 & 0.014 & 0.010 \\
\hline & $\mathrm{CHBrCl}_{2}$ & 0.006 & 0.010 & 0.013 & 0.019 & 0.035 & 0.017 \\
\hline & $\mathrm{CHBr}_{3}$ & 0.004 & 0.004 & 0.005 & 0.006 & 0.007 & 0.005 \\
\hline & $\mathrm{CHCl}_{3}$ & 0.009 & 0.019 & 0.019 & 0.037 & 0.039 & 0.025 \\
\hline & Mean Conc. & 0.006 & 0.011 & 0.012 & 0.019 & 0.024 & \\
\hline & CV\% & & $16.76 \%$ & & & & \\
\hline & $\mathrm{P} \leq 0.05$ & & $*$ & & & & * \\
\hline & Interaction & & NS & & & & \\
\hline \multirow{8}{*}{$\begin{array}{l}\text { SOD activity } \\
\mathrm{U} \mathrm{mg}^{-1}\end{array}$} & $\mathrm{CHBr}_{2} \mathrm{Cl}$ & 0.037 & 0.040 & 0.026 & 0.019 & 0.025 & 0.029 \\
\hline & $\mathrm{CHBrCl}_{2}$ & 0.024 & 0.007 & 0.002 & 0.010 & 0.013 & 0.011 \\
\hline & $\mathrm{CHBr}_{3}$ & 0.018 & 0.016 & 0.010 & 0.027 & 0.011 & 0.016 \\
\hline & $\mathrm{CHCl}_{3}$ & 0.056 & 0.036 & 0.012 & 0.051 & 0.079 & 0.047 \\
\hline & Mean Conc. & 0.034 & 0.025 & 0.012 & 0.027 & 0.032 & \\
\hline & CV\% & & $7.15 \%$ & & & & \\
\hline & $\mathrm{P} \leq 0.05$ & & NS & & & & * \\
\hline & Interaction & & $*$ & & & & \\
\hline \multirow{8}{*}{$\begin{array}{l}\text { BCA } \\
\mathrm{mg} / \mathrm{mL}\end{array}$} & $\mathrm{CHBr}_{2} \mathrm{Cl}$ & 101.67 & 87.771 & 72.176 & 67.668 & 52.380 & 76.320 \\
\hline & $\mathrm{CHBrCl}_{2}$ & 126.629 & 115.589 & 114.210 & 80.524 & 51.752 & 97.741 \\
\hline & $\mathrm{CHBr}_{3}$ & 184.608 & 209.798 & 243.993 & 302.665 & 311.946 & 250.602 \\
\hline & $\mathrm{CHCl}_{3}$ & 102.078 & 86.251 & 85.448 & 79.020 & 38.248 & 78.209 \\
\hline & Mean Conc. & 128.746 & 124.852 & 128.957 & 132.469 & 113.582 & \\
\hline & CV\% & & $4.18 \%$ & & & & \\
\hline & $\mathrm{P} \leq 0.05$ & & NS & & & & * \\
\hline & Interaction & & $*$ & & & & \\
\hline \multirow{4}{*}{$\begin{array}{l}\text { TBARS } \\
\mathrm{mM}^{-1} \mathrm{~cm}^{-1}\end{array}$} & $\mathrm{CHBr}_{2} \mathrm{Cl}$ & 0.838 & 0.988 & 1.547 & 2.925 & 3.049 & 1.869 \\
\hline & $\mathrm{CHBrCl}_{2}$ & 2.191 & 2.416 & 3.403 & 3.947 & 3.983 & 3.188 \\
\hline & $\mathrm{CHBr}_{3}$ & 1.761 & 2.100 & 3.058 & 3.442 & 4.034 & 2.879 \\
\hline & $\mathrm{CHCl}_{3}$ & 1.393 & 1.819 & 2.516 & 3.132 & 3.280 & 2.428 \\
\hline
\end{tabular}


Table 3: Continue

\begin{tabular}{lllllll} 
Mean Conc. & 1.546 & 1.831 & 2.631 & 3.362 & 3.587 & \\
CV\% & & $3.55 \%$ & & & & $*$ \\
$\mathrm{P} \leq 0.05$ & $*$ & & & & \\
Interaction & & $*$ & & & \\
\hline
\end{tabular}

Values presented are the mean values calculated from the sum of both TMM $=$ tomato moneymaker and TS $=$ tomato star means divided by $\mathrm{n}=2$ each with $\mathrm{n}=4$ replicates, $*=$ significance at $\mathrm{P} \leq 0.05$ respectively; $\mathrm{NS}=$ not significant, $\mathrm{CHBrCl}_{2}=\mathrm{Bromodichloromethane,} \mathrm{CHBr}_{3}=$ Bromoform, $\mathrm{CHCl}_{3}=$ Chloroform, $\mathrm{CHBr}_{2} \mathrm{Cl}=$ Dibromochloromethane $\mathrm{FRAP}=$ Ferric reducing ability of plasma, $\mathrm{ORAC}=\mathrm{Oxygen}$ radical absorbance capacity, $\mathrm{APx}=$ Ascorbate peroxidase, $\mathrm{GPx}=$ Guaiacol peroxidase, $\mathrm{SOD}=$ Superoxide dismutase, $\mathrm{BCA}=$ pierce bicinchoninic acid protein assay, TBARS $=$ Thiobarbituric acid reaction for general lipid peroxidation

Table 4: Effects of trihalomethane chemical species at $10 \mathrm{mgL}^{-1}$ on non-enzymatic and enzymatic biomarkers of oxidative stress in lyophilized leaf tissues of the tomato cultivars ( 30 days treatment data)

Chemical species

\begin{tabular}{|c|c|c|c|c|c|c|}
\hline & Plant Varieties & $\mathrm{CHBr}_{2} \mathrm{Cl}$ & $\mathrm{CHBrCl}_{2}$ & $\mathrm{CHBr}_{3}$ & $\mathrm{CHCl}_{3}$ & Mean $p$ variety \\
\hline \multirow{6}{*}{$\begin{array}{l}\text { Polyphenols } \\
\text { mg.L }{ }^{-1} \text { (GAE) }\end{array}$} & TMM & 3.832 & 6.965 & 12.435 & 16.755 & 9.997 \\
\hline & TS & 3.439 & 7.258 & 11.747 & 16.052 & 9.624 \\
\hline & Mean $\mathrm{C}$ varieties & 3.635 & 7.112 & 12.091 & 16.40 & \\
\hline & CV\% & & $3.05 \%$ & & & \\
\hline & $\mathrm{P} \leq 0.05$ & & $*$ & & & NS \\
\hline & Interaction & & NS & & & \\
\hline \multirow{5}{*}{$\begin{array}{l}\text { FRAP } \\
\text { mg.L }{ }^{-1} \text { (AAE) }\end{array}$} & TMM & 22.172 & 31.169 & 40.241 & 43.801 & 34.346 \\
\hline & TS & 19.370 & 29.918 & 35.465 & 42.257 & 31.753 \\
\hline & $\begin{array}{l}\text { Mean } \mathrm{C} \text { varieties } \\
\mathrm{CV} \%\end{array}$ & 20.771 & $\begin{array}{l}30.543 \\
2.93 \%\end{array}$ & 37.853 & 43.029 & \\
\hline & $\mathrm{P} \leq 0.05$ & & * & & & NS \\
\hline & Interaction & & NS & & & \\
\hline \multirow{6}{*}{$\begin{array}{l}\text { ORAC } \\
\text { mM trolox }\end{array}$} & TMM & 7.175 & 10.726 & 7.755 & 26.020 & 12.919 \\
\hline & TS & 6.188 & 10.576 & 9.325 & 23.309 & 12.350 \\
\hline & Mean $\mathrm{C}$ varieties & 6.681 & 10.651 & 8.540 & 24.665 & \\
\hline & CV\% & & $3.28 \%$ & & & \\
\hline & $\mathrm{P} \leq 0.05$ & & $*$ & & & NS \\
\hline & Interaction & & NS & & & \\
\hline \multirow{6}{*}{$\mathrm{U} \mathrm{mg}^{-1}$} & TMM & 0.005 & 0.016 & 0.002 & 0.024 & 0.012 \\
\hline & TS & 0.004 & 0.012 & 0.002 & 0.042 & 0.015 \\
\hline & Mean $\mathrm{C}$ varieties & 0.004 & 0.014 & 0.002 & 0.033 & \\
\hline & CV\% & & $24.54 \%$ & & & \\
\hline & $\mathrm{P} \leq 0.05$ & & $*$ & & & NS \\
\hline & Interaction & & NS & & & \\
\hline GPX activity & TMM & 0.010 & 0.021 & 0.005 & 0.026 & 0.016 \\
\hline \multirow[t]{5}{*}{$\mathrm{U} \mathrm{mg}^{-1}$} & TS & 0.011 & 0.013 & 0.005 & 0.023 & 0.013 \\
\hline & Mean $C$ varieties & 0.010 & 0.017 & 0.005 & 0.025 & \\
\hline & CV\% & & $16.76 \%$ & & & \\
\hline & $\mathrm{P} \leq 0.05$ & & * & & & NS \\
\hline & Interaction & & NS & & & \\
\hline SOD activity & TMM & 0.031 & 0.012 & 0.020 & 0.044 & 0.027 \\
\hline \multirow[t]{5}{*}{$\mathrm{U} \mathrm{mg}^{-1}$} & TS & 0.028 & 0.010 & 0.013 & 0.050 & 0.025 \\
\hline & Mean $C$ varieties & 0.029 & 0.011 & 0.016 & 0.047 & \\
\hline & CV\% & & $7.15 \%$ & & & \\
\hline & $\mathrm{P} \leq 0.05$ & & NS & & & NS \\
\hline & Interaction & & NS & & & \\
\hline \multirow{6}{*}{$\begin{array}{l}\mathrm{BCA} \\
\mathrm{mg} / \mathrm{mL}\end{array}$} & TMM & 76.823 & 113.899 & 283.550 & 70.215 & 136.122 \\
\hline & TS & 75.817 & 81.583 & 217.654 & 86.203 & 115.314 \\
\hline & Mean $\mathrm{C}$ varieties & 76.320 & 97.741 & 250.602 & 78.209 & \\
\hline & CV\% & & $4.18 \%$ & & & \\
\hline & $\mathrm{P} \leq 0.05$ & & NS & & & $*$ \\
\hline & Interaction & & $*$ & & & \\
\hline \multirow{6}{*}{$\mathrm{mM}^{-1} \mathrm{~cm}^{-1}$} & TMM & 1.872 & 3.220 & 3.005 & 2.329 & 2.607 \\
\hline & TS & 1.867 & 3.156 & 2.753 & 2.526 & 2.576 \\
\hline & Mean $\mathrm{C}$ varieties & 1.869 & 3.188 & 2.879 & 2.428 & \\
\hline & CV\% & & $3.55 \%$ & & & \\
\hline & $\mathrm{P} \leq 0.05$ & & NS & & & NS \\
\hline & Interaction & & NS & & & \\
\hline
\end{tabular}

Values presented are means of $\mathrm{n}=4$ replicates, ${ }^{*}=$ significance at $\mathrm{P} \leq 0.05$ respectively; $\mathrm{NS}=$ not significant, TMM $=$ tomato moneymaker, TS = tomato star. $\mathrm{CHBrCl}_{2}=$ Bromodichloromethane, $\mathrm{CHBr}_{3}=$ Bromoform, $\mathrm{CHCl}_{3}=\mathrm{Chloroform}_{,} \mathrm{CHBr} \mathrm{Cl}_{2} \mathrm{Cl}=$ Dibromochloromethane FRAP $=$ Ferric reducing ability of plasma, ORAC $=$ Oxygen radical absorbance capacity, APx $=$ Ascorbate peroxidase, $\mathrm{GPx}=$ Guaiacol peroxidase, $\mathrm{SOD}=$ Superoxide dismutase, $\mathrm{BCA}=$ pierce bicinchoninic acid protein assay, TBARS $=$ Thiobarbituric acid reaction for general lipid peroxidation 
The average percentage increase in antioxidant parameters measured from control plants to those exposed to $10 \mathrm{mg} . \mathrm{L}^{-1}$ of trihalomethanes were total polyphenols $(44.79 \%)$, FRAP $(55.51 \%)$, ORAC $(71.13 \%)$, ascorbate peroxidase (APX) activity (366.67\%), guaiacol peroxidase (GPX) activity (300\%) and TBARS (132.02\%). The antioxidant parameters that increased significantly at $\mathrm{P} \leq 0.05$ as a response to an increasing chlorination order (except for $\mathrm{CHBr}_{3}$ ) of $\mathrm{CHBr}_{2} \mathrm{Cl}<\mathrm{CHBrCl}_{2}<\mathrm{CHBr}_{3}<\mathrm{CHCl}_{3}$ kept at a constant concentration of $10 \mathrm{mg} . \mathrm{L}^{-1}$ in both tomato cultivars include total polyphenols and the Ferric Reducing Antioxidant Power (FRAP). The Oxygen Radical Absorbance Capacity (ORAC) increased significantly at $\mathrm{P} \leq 0.05$ with a slightly different chlorination order of $\mathrm{CHBr}_{2} \mathrm{Cl}<\mathrm{CHBr}_{3}<\mathrm{CHBrCl}_{2}<\mathrm{CHCl}_{3}$ in both tomato cultivars, while the activities of both Ascorbate Peroxidase (APX) and Guaiacol Peroxidase (GPX) increased significantly at $\mathrm{P} \leq 0.05$ with the chlorination order of $\mathrm{CHBr}_{3}<\mathrm{CHBr}_{2} \mathrm{Cl}<\mathrm{CHBrCl}_{2}<\mathrm{CHCl}_{3}$ in both tomato cultivars (Table 4).

The percentage increase in antioxidant parameters from the effects of mono-chlorinated to the trichlorinated trihalomethanes were in total phenolic content (351.25\%), FRAP $(107.16 \%)$, ORAC $(269.18 \%)$, APX activity $(725 \%)$ and GPX activity $(150 \%)$. There was no response to increasing trihalomethane concentration or increasing halogenation observed in the activity of Superoxide Dismutase (SOD). The antioxidant parameters that were significantly affected at $\mathrm{P} \leq 0.05$ by both increasing chlorination and concentration of trihalomethanes in both tomato cultivars tested can be seen in Fig. 3.

A comparison between the effects of increasing trihalomethane concentration and the effects of increasing chlorination on the percentage increase in antioxidant parameters can be seen in Fig. 4. The effects of increasing halogenation induced a greater response in all antioxidant parameters with the exception of the activities of guaiacol peroxidase that appear to be more sensitive to the effects of increasing trihalomethane concentration.

\section{Effects of Trihalomethane Halogenation on the Sterol Content of the Tomato Leaf Oils}

In general, the sterol content of the tomato leaf oils on exposure to the trihalomethanes increased with an increasing degree of chlorination with the exception of $\beta$ sitosterol which decreased with increasing chlorination. There was no significant difference at $\mathrm{P} \leq 0.05$ in stigmasterol levels in leaf oils of control plants and the plants exposed to the mono-chlorinated trihalomethanes in both tomato cultivars as seen in Fig. 5 .

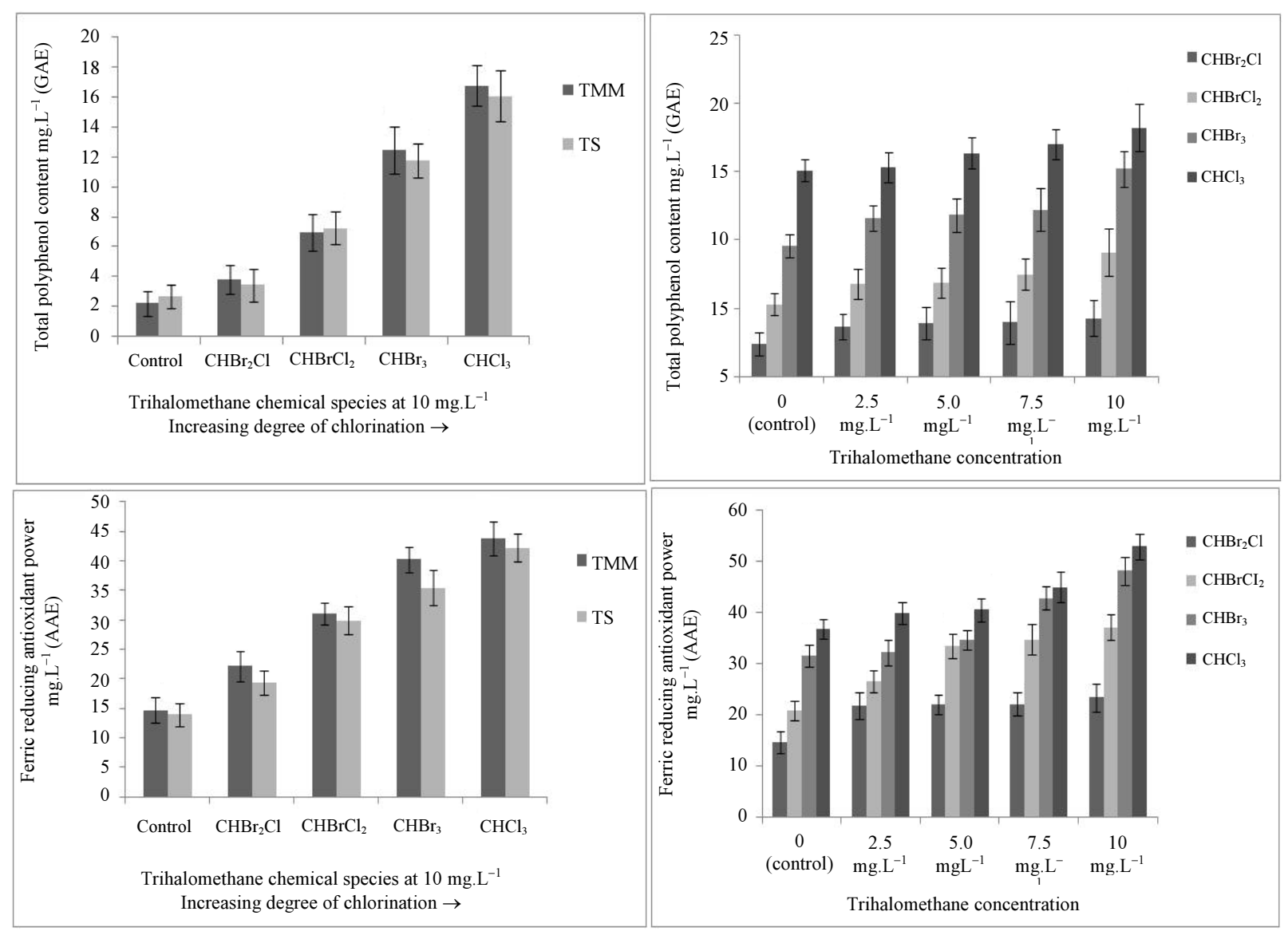




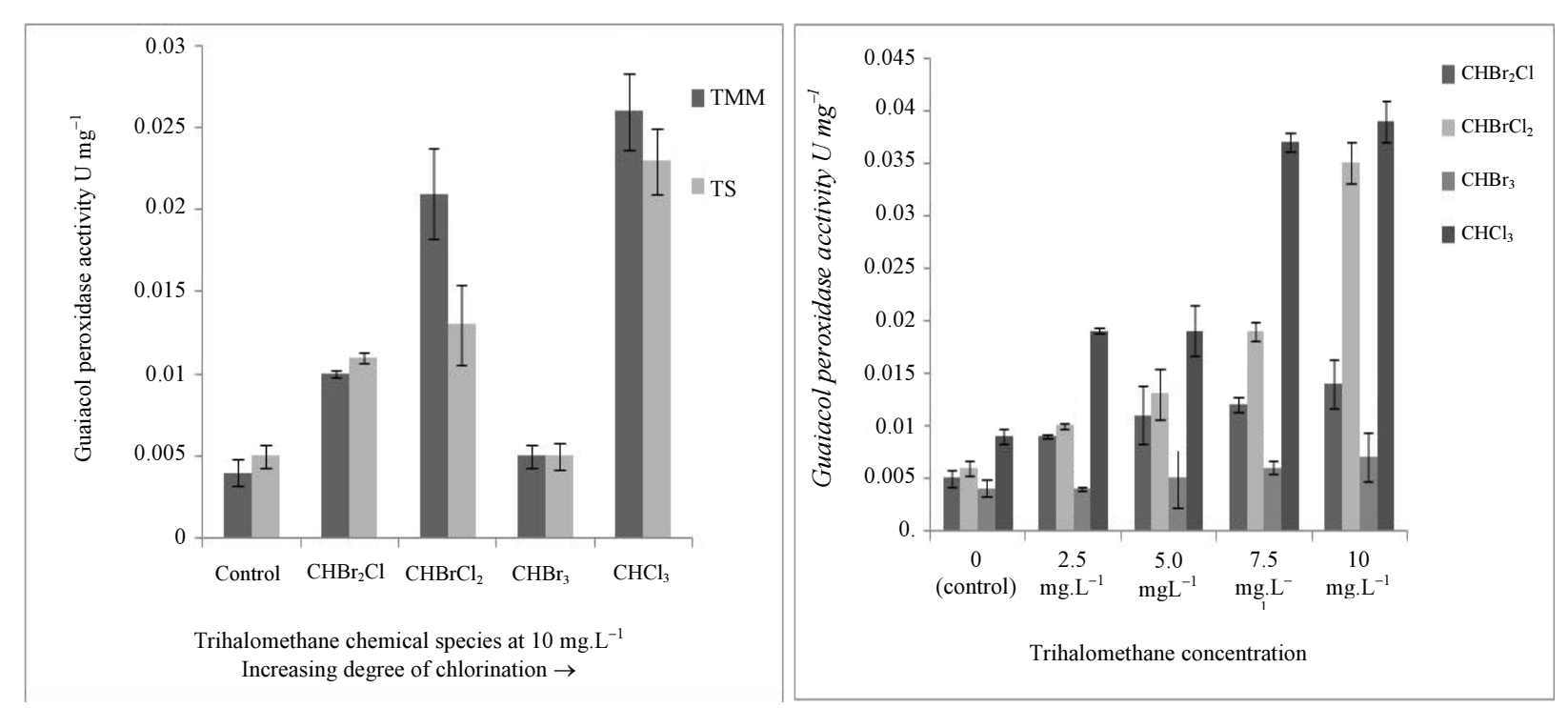

Fig. 3: Effects of the increasing order of trihalomethane chlorination and concentration on the antioxidant response of the both tomato cultivars. Control plants were exposed to deionized water containing plant nutrients only. Means followed by similar letter in a column are not significantly different from each other at $\mathrm{P} \leq 0.05$ according to FSD. Vertical bars represent standard error of means $(n=4)$. Mean values from the same cultivar and the same chemical treatment were compared with each other only; Values presented in the concentration graphs are the mean values calculated from the sum of both TMM = tomato moneymaker and TS $=$ tomato star means divided by $n=2$ each with $n=4$ replicates

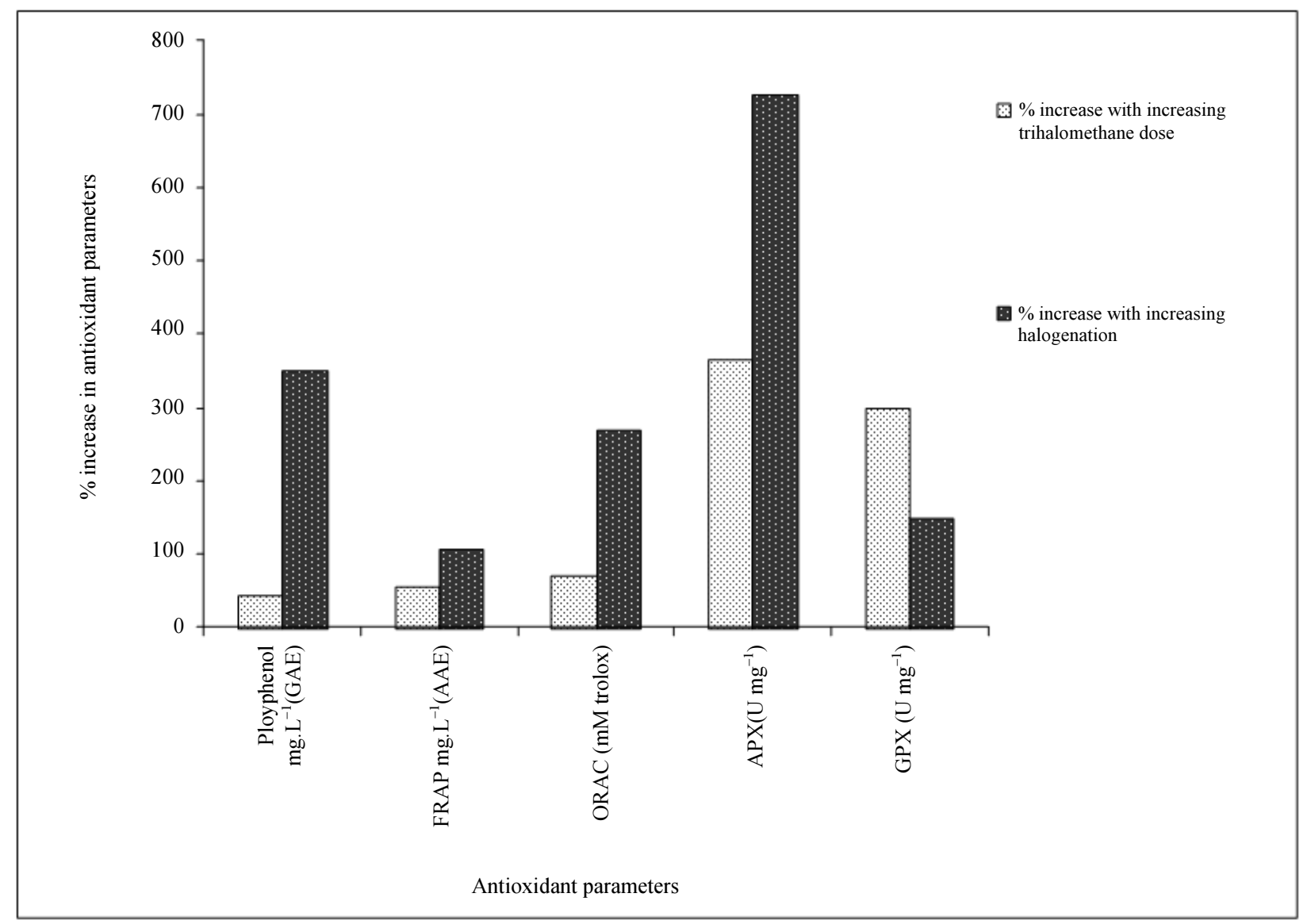

Fig. 4: Comparison between the effects of increasing trihalomethane dose and increasing halogenation on the antioxidant response of tomato plants after a 30 day exposure 


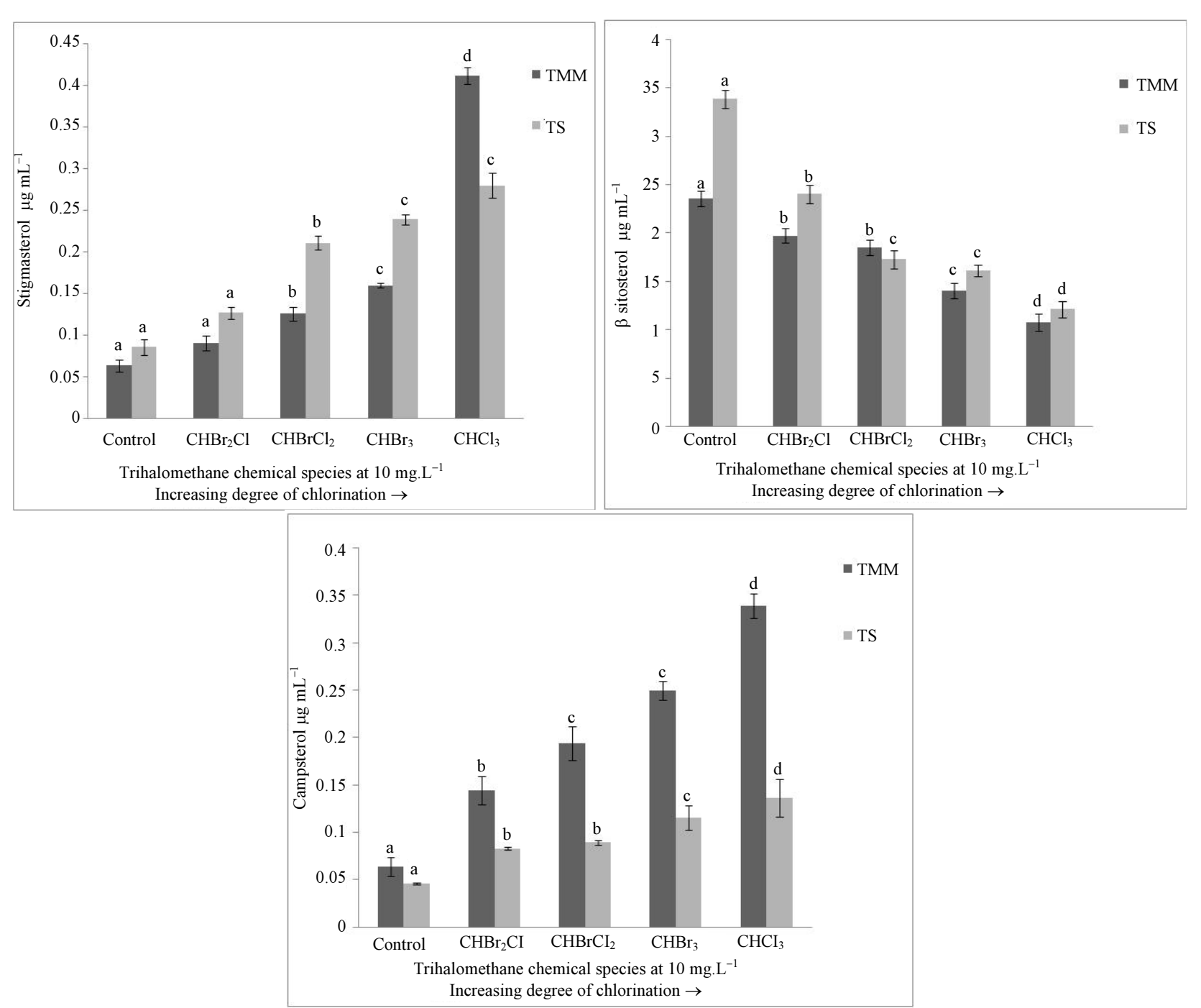

Fig. 5: Effects of the increasing order of trihalomethane chlorination on the sterol content of leaf oils in both tomato cultivars. Control plants were exposed to deionized water containing plant nutrients only. Means followed by a similar letter in a column are not significantly different from each other at $\mathrm{P} \leq 0.05$ according to FSD. Vertical bars represent standard error of means $(n=4)$. Mean values from the same cultivar were compared with each other only

\section{Discussion}

The degree of the phytotoxic effect of a refractory organic on vascular plants in principle depends on the physical and chemical properties of the compound. Hence, subtle changes affecting crop yield as a result of chemical exposure can be monitored through biochemical parameters in plant physiology. The physical and chemical properties of halogenated organics in nature induce phytotoxic effects simultaneously on plants. Hence, it is often difficult to elucidate which physical or chemical property of a compound is responsible for the greater phytotoxic effect. To our knowledge, few studies have been carried out in this field mainly because it is not feasible for chemical manufacturers to test plant sensitivity of all products on every species and cultivar. However, trihalomethanes are commonly detected in all surface waters as a result of chlorine disinfection during water treatment (Al-Otoum et al., 2016).

In this study, a significant decrease at $\mathrm{P} \leq 0.05$ in the nutrient levels of nitrogen, potassium and boron was induced by both the physical property of increasing concentration and the chemical property of the increasing number of chlorine atoms in trihalomethanes on both tomato cultivars (Fig. 1). Nitrogen deficiency in plants as been associated with loss of plant biomass, leaf area and leaf chlorophyll content (Zhao et al., 2005). Potassium plays a significant role in alleviating the detrimental effects of oxidative stress in plants but its 
deficiency causes increased loss in photosynthetic $\mathrm{CO}_{2}$ fixation and impaired partitioning and utilization of photosynthates (Cakmak, 2005). Boron deficiency in plants has been known to affect water uptake by inhibiting root and shoot growth, affect the photosynthetic mechanism and induce adverse metabolic pathways in leaves (Wimmer and Eichert, 2013). These symptoms of boron deficiency were considered as secondary effects of boron induced changes in membrane permeability (Pilbeam and Kirkby, 1983).

In general, the chemical property of the increasing number of chlorine atoms in trihalomethanes induced a greater decrease in nutrient levels when compared with the effect of increasing concentration (Fig. 2). A possible theory suggests that during the detoxification of chlorinated compounds by peroxidases in plants (Park et al., 2000; Talano et al., 2012), mono-oxygenase enzymes actively participate in the dehalogenation process leading to the formation of free $\mathrm{Cl}^{-}$radicals that may damage nutrient transport proteins in the tomato cultivars. However, the effect of concentration was greater on the decrease in nutrient levels of the divalent micronutrients $\mathrm{Cu}^{2+}$ and $\mathrm{Zn}^{2+}$ when compared with the effect of increasing halogenation in both tomato cultivars (Fig. 2). In the past, research has revealed that plant genomes contain several gene families specifically involved in the transport of divalent micro-nutrients (Mäser et al., 2001). This suggests that the mechanism of uptake and translocation of divalent cations in plants may differ from other nutrient categories and hence the effects of chemical exposure may also differ.

The antioxidant parameters that increased significantly in response to the effect of increasing concentration and the effect of the increasing halogenation of the trihalomethanes in both tomato cultivars include the total polyphenol content, the Ferric Reducing Antioxidant Power (FRAP) and the activity of Guaiacol Peroxidase (GPX) (Fig. 3). Plants are known to increase their phenolic content as a non-enzymatic response to free radical production from oxidative stress (Nogués et al., 2014). The exposure of plants to chlorinated organic compounds has been reported to induce the production of the peroxide $\mathrm{H}_{2} \mathrm{O}_{2}$ free radical (Menone et al., 2008; Michalowicz and Duda, 2009; San Miguel et al., 2012). The FRAP assay measures the total antioxidant power of biological fluids and as such most non-enzymatic activity (scavenging of free radicals) is mediated by redox reactions. The antioxidant activity of plant phenols mainly due to their redox potential has been extensively documented (Agati et al., 2012; Dangles, 2012; Martín et al., 2015). Hence, strong correlations have been reported between the increase in plant phenols and the FRAP values (Reyes-Carmona et al., 2005; Bunea et al., 2011; Ma et al., 2011). The increase in the activity of the enzyme guaiacol peroxidase by both the effect of the increasing trihalomethane concentration and halogenation in both tomato cultivars further confirms the production of the peroxide $\mathrm{H}_{2} \mathrm{O}_{2}$ radical due to chemical exposure. Guaiacol peroxidase, located in the vacuole, cytosol, cell wall and apoplast forms part of the Peroxidase (POX) complex of enzymes that detoxifies peroxide $\left(\mathrm{H}_{2} \mathrm{O}_{2}\right)$ using guaiacol (2-methoxyphenol) as its reducing substrate (Mika and Lüthje, 2003).

In general, the effect of the increasing degree of chlorination in trihalomethanes induced a greater measure of oxidative stress in the tomato cultivars when compared to the effect of increasing concentration (Fig. 4). However, the peroxidase enzymes responded differently with the activity of Guaiacol Peroxidase (GPX) being more sensitive to increasing trihalomethane concentration as opposed to halogenation. The activity of the Ascorbate Peroxidase (APX) enzymes, on the other hand, proved more sensitive to increasing trihalomethane halogenation. Ascorbate Peroxidase (APX) enzyme is the most important in $\mathrm{H}_{2} \mathrm{O}_{2}$ detoxification to water using ascorbate as substrate and has been reported to be the first line of defense and major $\mathrm{H} 2 \mathrm{O} 2$ scavenger in plants (Jebara et al., 2005). Many studies report the increase in the activity of the Peroxidase (POX) enzymes to environmental stressors (Sulmon et al., 2015; Czégény et al., 2016) but our findings suggest that their sensitivities may vary based on the properties of a chemical stressor.

The effects of the increasing chlorination of trihalomethanes resulted in an increase in the levels of stigmasterol and campesterol in leaf oils with the exception of $\beta$-sitosterol where a decrease was observed Fig. 5). The decrease in $\beta$-sitosterol has been reported to increase the permeability of plasma membrane for ions and SH-containing molecules (Valitova et al., 2011). This alteration in membrane function as a result of $\beta$ sitosterol depletion may be a mechanism in the tomato cultivars to combat decreasing nutrient levels by increasing membrane permeability for nutrients. However, many studies report the increase in phytosterol levels in plants under environmental and chemical stressors (Briceño et al., 2012; Ruggiero et al., 2013; Kumar et al., 2015).

In this study, the magnitude of the physiological response of tomato cultivars to the increasing degree of chlorination in trihalomethanes was greater in most parameters observed. It must be stated that at the concentration levels and chemical properties tested, no plant death was recorded in these experiments. While the limits for most chlorinated organics in international guidelines are concentration based, attention should be given to some chemical properties of the chlorinated organics in assessing potential phytotoxicity.

\section{Conclusion}

Data from the current study reports for the first time the probability of a halogenated compound such as the 
trihalomethanes displaying a disruptive effect on nutrient levels, inducing oxidative stress and altering phytosterol levels in tomato cultivars. These physiological alterations in the tomato cultivars due to chemical exposure appear to be more a function of the degree of chlorination rather than their concentration levels. The theory proposed in this study suggests that the increase in the amount of free radical $\mathrm{Cl}^{-}$ ions released during the dehalogenation processes in the tomato cultivars may cause more physiological harm than an increase in concentration. The physiological responses to the increasing trihalomethane concentration and halogenation were non-fatal since no plant death was recorded even at the highest concentrations tested.

\section{Author's Contributions}

Babatunde C. Akande: Researcher.

Olalekan S. Fatoki: Research supervisor and analytical/environmental chemistry.

James P. Odendaal: Research co-supervisor and ecotoxicology.

Jeanine L. Marnewick: Biochemical oxidative stress.

Patrick Ndakidemi: Plant diversity and taxonomy.

Olatunde S. Olatunji: Analytical/environmental chemistry.

\section{Ethics}

This article is original and contains unpublished material. The corresponding author confirms that all of the other authors have read and approved the manuscript and there are no ethical issues involved.

\section{References}

Agati, G., E. Azzarello, S. Pollastri and M. Tattini, 2012. Flavonoids as antioxidants in plants: Location and functional significance. Plant Sci., 196: 67-76. DOI: 10.1016/j.plantsci.2012.07.014

Ahammed, G.J., Y.P. Ruan, J. Zhou, X.J. Xia and K. Shi et al., 2013. Brassinosteroid alleviates polychlorinated biphenyls-induced oxidative stress by enhancing antioxidant enzymes activity in tomato. Chemosphere, 90: 2645-2653.

DOI: 10.1016/j.chemosphere.2012.11.041

Ainsworth, E.A. and K.M. Gillespie, 2007. Estimation of total phenolic content and other oxidation substrates in plant tissues using Folin-Ciocalteu reagent. Nature Protocols, 2: 875-877.

DOI: $10.1038 /$ nprot.2007.102

Al-Otoum, F., M.A. Al-Ghouti, T.A. Ahmed, M. Abu-Dieyeh and M. Ali, 2016. Disinfection byproducts of chlorine dioxide (chlorite, chlorate and trihalomethanes): Occurrence in drinking water in Qatar. Chemosphere, 164: 649-656.

DOI: 10.1016/j.chemosphere.2016.09.008
Barondeau, D.P., C.J. Kassmann, C.K. Bruns, J.A. Tainer and E.D. Getzoff, 2004. Nickel superoxide dismutase structure and mechanism. Biochemistry, 43: 8038-8047. DOI: 10.1021/bi0496081

Benzie, I.F. and J. Strain, 1996. The ferric Reducing Ability of Plasma (FRAP) as a measure of "antioxidant power": The FRAP Assay. Analy Biochem, 239: 70-76. DOI: 10.1006/abio.1996.0292

Bergmeyer, H.U., K. Gawehn and M. Grassl, 1974. Enzymes As Biochemical Reagents. In: Methods of Enzymatic Analysis, Bergmeyer, H.U. (Ed.), Academic Press, New York, pp: 425-521.

Briceño, Z., L. Almagro, A.B. Sabater-Jara, A.A. Calderón and M.A. Pedreño et al., 2012. Enhancement of phytosterols, taraxasterol and induction of extracellular pathogenesis-related proteins in cell cultures of Solanum lycopersicum cv Micro-Tom elicited with cyclodextrins and methyl jasmonate. J. Plant Physiol., 169: 1050-1058.

DOI: 10.1016/j.jplph.2012.03.008

Bunea, A., D.O. Rugină, A.M. Pintea, Z. Sconta and C.I. Bunea et al., 2011. Comparative polyphenolic content and antioxidant activities of some wild and cultivated blueberries from Romania. Notulae Botanicae Horti Agrobotanici Cluj-Napoca, 39: 70-76. DOI: $10.15835 /$ nbha3926265

Cakmak, I., 2005. The role of potassium in alleviating detrimental effects of abiotic stresses in plants. J Plant Nutr. Soil Sci., 168: 521-530.

DOI: 10.1002/jpln.200420485

Campbell, C.R. and C.O. Plank, 1998. Preparation of plant tissue for laboratory analysis. Methods Plant Anal.

Chen, Y., Y. Wen, Z. Tang, L. Li and Y. Cai et al., 2014. Removal processes of disinfection byproducts in subsurface-flow constructed wetlands treating secondary effluent. Water Res., 51: 163-171.

DOI: $10.1016 /$ j.watres.2013.12.027

Czégény, G., B. Le Martret, D. Pávkovics, P.J. Dix and É. Hideg, 2016. Elevated ROS-scavenging enzymes contribute to acclimation to UV-B exposure in transplastomic tobacco plants, reducing the role of plastid peroxidases. J. Plant Physiol., 201: 95-100. DOI: 10.1016/j.jplph.2016.05.026

Dangles, O., 2012. Antioxidant activity of plant phenols: Chemical mechanisms and biological significance. Curr. Org. Chem., 16: 692-714. DOI: $10.2174 / 138527212799957995$

Doucette, W., H. Klein, J. Chard, R. Dupont and W. Plaehn et al., 2013. Volatilization of trichloroethylene from trees and soil: Measurement and scaling approaches. Environ. Sci. Technol., 47: 5813-5820. DOI: 10.1021/es304115c

Ellerby, L.M. and D.E. Bredesen, 2000. Measurement of cellular oxidation, reactive oxygen species and antioxidant enzymes during apoptosis. Methods Enzymol., 322: 413-421.

DOI: $10.1016 / \mathrm{S} 0076-6879(00) 22040-5$ 
Farmer, E.E. and M.J. Mueller, 2013. ROS-mediated lipid peroxidation and RES-activated signaling. Ann. Rev. Plant Biol., 64: 429-450.

DOI: 10.1146/annurev-arplant-050312-120132

Faure, M., A. San Miguel, P. Ravanel and M. Raveton, 2012. Concentration responses to organochlorines in Phragmites australis. Environ. Pollut., 164: 188-194. DOI: 10.1016/j.envpol.2012.01.040

Guittonny-Philippe, A., V. Masotti, I. Combroux, L. Malleret and J.L. Boudenne et al., 2015. Proposal of a new ecotoxicity evaluation tool based on morphological responses of five helophytes to mixtures of pollutants: The Helophyte development index. Ecol. Eng., 77: 180-188.

DOI: 10.1016/j.ecoleng.2015.01.022

Gutteridge, J. and B. Halliwell, 2000. Free radicals and antioxidants in the year 2000: A historical look to the future. Ann. New York Acad. Sci., 899: 136-147. DOI: $10.1111 / \mathrm{j} .1749-6632.2000 . t b 06182 . x$

Habartová, A., K.T. Valsaraj an M. Roeselová, 2013. Molecular dynamics simulations of small halogenated organics at the air-water interface: Implications in water treatment and atmospheric chemistry. J. Phys. Chem. A, 117: 9205-9215. DOI: $10.1021 / \mathrm{jp} 405292 \mathrm{k}$

Havlin, J., D. Hardy, R. Gehl and S. Spayd, 2012. Survey of nutrient status in vitis vinifera grapes in North Carolina. Commun. Soil Sci. Plant Anal., 43: 299-314. DOI: 10.1080/00103624.2011.638600

Heath, R.L. and L. Packer, 1968. Photoperoxidation in isolated chloroplasts: I. Kinetics and stoichiometry of fatty acid peroxidation. Arch. Biochem. Biophys., 125: 189-198. DOI: 10.1016/0003-9861(68)90654-1

Hodges, D.M., J.M. Delong, C.F. Forney and R.K. Prange, 1999. Improving the thiobarbituric acidreactive-substances assay for estimating lipid peroxidation in plant tissues containing anthocyanin and other interfering compounds. Planta, 207: 604-611. DOI: 10.1007/s004250050524

Hodgeson, J. and A. Cohen, 1990. Determination of Chlorination Disinfection Byproducts and Chlorinated Solvents in Drinking Water by Liquidliquid Extraction and Gas Chromatography with Electron-capture Detection: Method 551. Environmental Monitoring Systems Laboratory, Office of Research and Development, US Environmental Protection Agency.

Imfeld, G., M. Braeckevelt, P. Kuschk and H.H. Richnow, 2009. Monitoring and assessing processes of organic chemicals removal in constructed wetlands. Chemosphere, 74: 349-362.

DOI: $10.1016 / \mathrm{j}$.chemosphere.2008.09.062

Jebara, S., M. Jebara, F. Limam and M.E. Aouani, 2005. Changes in ascorbate peroxidase, catalase, guaiacol peroxidase and superoxide dismutase activities in common bean (Phaseolus vulgaris) nodules under salt stress. J. Plant Physiol., 162: 929-936.

DOI: $10.1016 /$ j.jplph.2004.10.005
Kumar, M.S.S., K. Ali, A. Dahuja and A. Tyagi, 2015. Role of phytosterols in drought stress tolerance in rice. Plant Physiol. Biochem., 96: 83-89. DOI: $10.1016 /$ j.plaphy.2015.07.014

Lapornik, B., M. Prošek and A. Golc Wondra, 2005. Comparison of extracts prepared from plant byproducts using different solvents and extraction time. J. Food Eng., 71: 214-222. DOI: 10.1016/j.jfoodeng.2004.10.036

Li, W., Y. Shi, L. Gao, J. Liu and Y. Cai, 2015. Occurrence, fate and risk assessment of parabens and their chlorinated derivatives in an advanced wastewater treatment plant. J Haz. Mat., 300: 29-38. DOI: $10.1016 /$ j.jhazmat.2015.06.060

Lykkesfeldt, J., 2007. Malondialdehyde as biomarker of oxidative damage to lipids caused by smoking. Clin. Chim. Acta, 380: 50-58. DOI: 10.1016/j.cca.2007.01.028

Ma, X., H. Wu, L. Liu, Q. Yao and S. Wang et al., 2011. Polyphenolic compounds and antioxidant properties in mango fruits. Sci. Horticul., 129: 102-107. DOI: 10.1016/j.scienta.2011.03.015

Martín, M.A., S. Ramos, R. Mateos, J.P. Marais and L. Bravo-Clemente et al., 2015. Chemical characterization and chemo-protective activity of cranberry phenolic powders in a model cell culture. Response of the antioxidant defenses and regulation of signaling pathways. Food Res. Int., 71: 68-82. DOI: 10.1016/j.foodres.2015.02.022

Mäser, P., S. Thomine, J.I. Schroeder, J.M. Ward and K. Hirschi et al., 2001. Phylogenetic relationships within cation transporter families of arabidopsis. Plant Physiol., 126: 1646-1667.

DOI: $10.1104 /$ pp. 126.4.1646

Matyash, V., G. Liebisch, T.V. Kurzchalia, A. Shevchenko and D. Schwudke, 2008. Lipid extraction by methylterf-butyl ether for high-throughput lipidomics. J. Lipid. Res., 49: 1137-1146.

DOI: 10.1194/jlr.D700041-JLR200

Menone, M.L., S.F. Pesce, M.P. Díaz, V.J. Moreno and D.A. Wunderlin, 2008. Endosulfan induces oxidative stress and changes on detoxication enzymes in the aquatic macrophyte Myriophyllum quitense. Phytochemistry, 69: 1150-1157.

DOI: $10.1016 /$ j.phytochem.2007.11.016

Meyer, A.S., O.S. Yi, D.A. Pearson, A.L. Waterhouse and E.N. Frankel, 1997. Inhibition of human lowdensity lipoprotein oxidation in relation to composition of phenolic antioxidants in grapes (Vitis vinifera). J. Agric. Food Chem., 45: 1638-1643.

DOI: $10.1021 /$ jf960721a

Michalowicz, J. and W. Duda, 2009. The effects of 2, 4, 5 -trichlorophenol on some antioxidative parameters and the activity of glutathione S-transferase in reed canary grass leaves (Phalaris arudinacea). Polish J. Environ. Stud., 18: 845-852. 
Mika, A. and S. Lüthje, 2003. Properties of guaiacol peroxidase activities isolated from corn root plasma membranes. Plant Physiol., 132: 1489-1498. DOI: $10.1104 /$ pp. 103.020396

Moeckel, C., G.O. Thomas, J.L. Barber and K.C. Jones, 2007. Uptake and storage of PCBs by plant cuticles. Environ. Sci. Technol., 42: 100-105. DOI: $10.1021 / \mathrm{es} 070764 \mathrm{f}$

Montelius, M., Y. Thiry, L. Marang, J. Ranger and J.T. Cornelis et al., 2015. Experimental evidence of large changes in terrestrial chlorine cycling following altered tree species composition. Environ. Sci. Technol., 49: 4921-4928.

DOI: $10.1021 /$ acs.est.5b00137

Nakano, Y. and K. Asada, 1981. Hydrogen peroxide is scavenged by ascorbate-specific peroxidase in spinach chloroplasts. Plant Cell Physiol., 22: 867-880.

Nogués, I., J. Llusià, R. Ogaya, S. Munné-Bosch and J. Sardans et al., 2014. Physiological and antioxidant responses of Quercus ilex to drought in two different seasons. Plant Biosyst. Int. J. Deal. Aspects Plant Biol., 148: 268-278.

DOI: $10.1080 / 11263504.2013 .768557$

Nzengung, V.A. and P. Jeffers, 2001. Sequestration, phytoreduction and phytooxidation of halogenated organic chemicals by aquatic and terrestrial plants. Int. J. Phytoremed., 3: 13-40. DOI: $10.1080 / 15226510108500048$

Pang, C.H. and B.S. Wang, 2010. Role of ascorbate peroxidase and glutathione reductase in ascorbateglutathione cycle and stress tolerance in plants. In: Ascorbate-Glutathione Pathway and Stress Tolerance in Plants, Anjum, N.A., U. Shahid and C. Ming-Tsair (Eds.), Springer Netherlands, pp: 91-113.

Park, J.W., J. Dec, J.E. Kim and J.M. Bollag, 2000. Transformation of chlorinated phenols and anilines in the presence of humic acid. J. Environ. Qual., 29: 214-220.

DOI: $10.2134 /$ jeq2000.00472425002900010027x

Phung, T.H. and S. Jung, 2015. Differential antioxidant defense and detoxification mechanisms in photodynamically stressed rice plants treated with the deregulators of porphyrin biosynthesis, 5aminolevulinic acid and oxyfluorfen. Biochem. Biophys. Res. Commun., 459: 346-351.

DOI: $10.1016 /$ j.bbrc.2015.02.125

Pi, N., S.E. Chia, C.N. Ong and B.C. Kelly, 2016. Associations of serum organohalogen levels and prostate cancer risk: Results from a case-control study in Singapore. Chemosphere, 144: 1505-1512. DOI: $10.1016 /$ j.chemosphere.2015.10.020
Pilbeam, D.J. and E.A. Kirkby, 1983. The physiological role of boron in plants. J. Plant Nutrit., 6: 563-582. DOI: $10.1080 / 01904168309363126$

Prior, R.L., H. Hoang, L. Gu, X. Wu and M. Bacchiocca et al., 2003. Assays for hydrophilic and lipophilic antioxidant capacity (Oxygen Radical Absorbance Capacity (ORACFL)) of plasma and other biological and food samples. J. Agric. Food Chem., 51: 3273-3279. DOI: 10.1021/jf0262256

Ramadan, M.F. and J.T. Moersel, 2006. Screening of the antiradical action of vegetable oils. J. Food Composit. Anal., 19: 838-842. DOI: $10.1016 /$ j.jfca.2006.02.013

Reichenauer, T.G. an J.J. Germida, 2008. Phytoremediation of organic contaminants in soil and groundwater. Chem. Sus. Chem., 1: 708-717. DOI: $10.1002 /$ cssc. 200800125

Reyes-Carmona, J., G.G. Yousef, R.A. Martínez-Peniche and M.A. Lila, 2005. Antioxidant capacity of fruit extracts of blackberry (Rubus sp.) produced in different climatic regions. J. food Sci., 70: 497-503. DOI: $10.1111 /$ j.1365-2621.2005.tb11498.x

Ruggiero, A., S. Vitalini, N. Burlini, S. Bernasconi and M. Iriti, 2013. Phytosterols in grapes and wine and effects of agrochemicals on their levels. Food Chem., 141: 3473-3479.

DOI: 10.1016/j.foodchem.2013.05.153

San Miguel, A., M. Faure, P. Ravanel and M. Raveton, 2012. Biological responses of maize (Zea mays) plants exposed to chlorobenzenes. Case study of monochloro-, 1, 4-dichloro-and 1, 2, 4-trichlorobenzenes. Ecotoxicology, 21: 315-324.

DOI: $10.1007 / \mathrm{s} 10646-011-0792-0$

San Miguel, A., P. Schröder, R. Harpaintner, T. Gaude and P. Ravanel et al., 2013. Response of phase II detoxification enzymes in Phragmites australis plants exposed to organochlorines. Environ. Sci. Pollut. Res., 20: 3464-3471.

DOI: $10.1007 / \mathrm{s} 11356-012-1301-6$

Scientific, T., 2011. Pierce BCA protein assay kit. Instruct. Manual.

Sulmon, C., J. Van Baaren, F. Cabello-Hurtado, G. Gouesbet and F. Hennion et al., 2015. Abiotic stressors and stress responses: What commonalities appear between species across biological organization levels? Environ. Pollut., 202: 66-77. DOI: 10.1016/j.envpol.2015.03.013

Susarla, S., V.F. Medina and S.C. Mccutcheon, 2002. Phytoremediation: An ecological solution to organic chemical contamination. Ecol. Eng., 18: 647-658. DOI: $10.1016 / \mathrm{S} 0925-8574(02) 00026-5$

Sweeney, R. and P. Rexroad, 1986. Comparison of LECO FP-228" nitrogen determinator" with AOAC copper catalyst Kjeldahl method for crude protein. J. Assoc. Off Anal. Chem., 70: 1028-1030. 
Talano, M.A., D.C. Busso, C.E. Paisio, P.S. González and S.A. Purro et al., 2012. Phytoremediation of 2, 4-dichlorophenol using wild type and transgenic tobacco plants. Environ. Sci. Pollut. Res., 19: 2202-2211. DOI: 10.1007/s11356-011-0724-9

Talbi, S., M.C. Romero-Puertas, A. Hernández, L. Terrón and A. Ferchichi et al., 2015. Drought tolerance in a Saharian plant Oudneya africana: Role of antioxidant defences. Environ. Exp. Bot., 111: 114-126. DOI: 10.1016/j.envexpbot.2014.11.004

Valitova, J.N., F.V. Minibayeva, E.R. Kotlova, A.V. Novikov and A.L. Shavarda et al., 2011. Effects of sterol-binding agent nystatin on wheat roots: The changes in membrane permeability, sterols and glycoceramides. Phytochem., 72:1751-1759.

DOI: $10.1016 /$ j.phytochem.2011.06.004

Van Aken, B., 2011. Transgenic Plants and Associated Bacteria for Phytoremediation of Organic Pollutants, Comprehensive Biotechnology. 2nd Edn.

Wang, C.Q., Y.F. Zhang and Y.B. Zhang, 2008. Scavenger enzyme activities in subcellular fractions of white clover (Trifolium repens L.) under PEGinduced water stress. J. Plant Growth Regul., 27: 387-393. DOI: 10.1007/s00344-008-9065-4

Wimmer, M.A. and T. Eichert, 2013. Review: Mechanisms for boron deficiency-mediated changes in plant water relations. Plant Sci., 203-204: 25-32. DOI: $10.1016 /$ j.plantsci.2012.12.012

Wolfe, N, C. Hoehamer, 2003. Enzymes Used by Plants and Microorganisms to Detoxify Organic Compounds. In: Phytoremediation: Transformation and Control of Contaminants, J.L. Schnoor and A. Zehnder (Eds.), John Wiley and Sons, Inc., pp: 159-187.
Wong, M.H., M.A. Armour, R. Naidu and M. Man, 2012. Persistent toxic substances: sources, fates and effects. Rev. Environ. Health, 27: 207-213. DOI: $10.1515 /$ reveh-2012-0040

Woo, Y.T., D.Y. Lai, J.C. Arcos, 2013. Aliphatic and Polyhalogenated Carcinogens: Structural Bases and Biological Mechanisms. Academic Press, USA, pp: 616.

Yang, Y., C. Han, Q. Liu, B. Lin and J. Wang, 2008. Effect of drought and low light on growth and enzymatic antioxidant system of Picea asperata seedlings. Acta Physiol. Plant, 30: 433-440. DOI: $10.1007 / \mathrm{s} 11738-008-0140-\mathrm{z}$

Zhang, A., W. Luo, J. Sun, H. Xiao and W. Liu, 2015. Distribution and uptake pathways of organochlorine pesticides in greenhouse and conventional vegetables. Sci. Total Environ., 505: 1142-1147. DOI: $10.1016 /$ j.scitotenv.2014.11.023

Zhao, D., K.R. Reddy, V.G. Kakani and V.R. Reddy, 2005. Nitrogen deficiency effects on plant growth, leaf photosynthesis and hyperspectral reflectance properties of sorghum. Eur. J. Agronomy, 22: 391-403. DOI: 10.1016/j.eja.2004.06.005

Zhou, Y., J. Yu, L. Huang and S. Nogués, 2004. The relationship between $\mathrm{CO} 2$ assimilation, photosynthetic electron transport and water-water cycle in chill-exposed cucumber leaves under low light and subsequent recovery. Plant Cell Environ., 27: 1503-1514.

DOI: $10.1111 /$ j.1365-3040.2004.01255.x 